\title{
Piper (Piperaceae) in New Guinea: the climbing species
}

\author{
R.O. Gardner ${ }^{1}$
}

Key words

New Guinea

Piper

taxonomy

\begin{abstract}
Sixteen climbing Piper species are accepted for New Guinea. The three endemics, $P$. arfakianum, $P$. subcanirameum and $P$. versteegii, are fully described. Eight taxa of unclear circumscription are noted. A new variety of $P$. macropiper, endemic to Morobe Province of Papua New Guinea, is described. The presence of an ant-plant piper in West New Guinea is noted.
\end{abstract}

Published on 1 March 2013

\section{INTRODUCTION}

Native climbing representatives of Piper (Piperaceae) are found in forests throughout New Guinea, from sea level to the montane/alpine transition at 2500-3500 m altitude. They are essentially tropical plants and occur mainly below $1500 \mathrm{~m}$. By comparison, the shrubby New Guinea pipers show a greater diversity, and possibly a greater ecological abundance too, above this level (Gardner 2003).

The first climbing pipers described from New Guinea were coastal ones: $P$. fragile Benth. in 1843 and $P$. seemannianum C.DC. ( $=$ P. celtidiforme Opiz) in 1866. Explorations by late nineteenth and early twentieth century expeditions then resulted in the describing of numerous new species, by German and English botanists but overwhelmingly by Piper specialist Casimir de Candolle (1836-1918) of Geneva.

In the first of his publications with names for New Guinean taxa ( $P$. lessertianum and $P$. seemannianum) De Candolle (1866) made no reference to the work of his predecessors on the pipers of neighbouring archipelagos (e.g. Opiz 1828, Miquel 1843-1844) and this pattern of naming as new almost every specimen sent to him was maintained throughout his career. His posthumous account of the genus as a whole (De Candolle 1923) contains many accurate observations, but is (as its title says) analytic rather than synthetic, with similar taxa distanced from one another through the use of trivial characters.

The 'splitter's baton' was taken up a decade after De Candolle's death by American botanist William Trelease, who published eleven new names in the genus (Trelease 1928) from collections made by the 1926-1927 Arnold Arboretum Expedition. He did not compare his taxa with any earlier-named ones, and I consider that all should go into synonymy ( $P$. melula Trel. was maintained by Chew (2003) but I do not). The latest (single) additional name for a climbing Piper of New Guinea, P. trombek P.Royen, must also be regarded as a synonym (Chew 1992).

Chew $(1972,1992,2003)$ has made a very substantial contribution towards clarifying the c. 100 New Guinean Piper names, by his examination of material from major herbaria, notably Berlin, whose Piper types largely escaped the destruction of World War II.

\footnotetext{
${ }^{1}$ Auckland War Memorial Museum, Private Bag 92018, Auckland, New Zealand; corresponding author e-mail: rhysogardner@hotmail.com.
}

The synoptic treatment offered here focuses on identification through the use of spot characters and illustrations. Sixteen species are accepted, although two of them, $P$. lessertianum and $P$. macropiper, are treated as unresolved species-complexes. Full descriptions are given just for the three species endemic to New Guinea - for descriptions of the others, and extensive synonymies, see Quisumbing (1930) and Chew (1972, 1992, 2003). Illustrations of the non-endemic thirteen species can be found in Quisumbing (1930) and Gardner (2006, 2010).

Another eight names for New Guinean taxa are discussed below under 'Incertae Sedis'.

\section{METHODS}

This study is based primarily on an examination of specimens from $A, A K, B, B I S H, C A N B$ and $K$, with a lesser number coming from BRIT and L. Many of them were determined by W.-L. Chew in the 1970s. The numerous high-quality specimens collected in recent years by $\mathrm{W}$. Takeuchi (LAE) have also been very instructive.

\section{SCOPE}

All of the climbing Piper species that grow wild (or seemingly wild, in the case of $P$. betle) are treated. The cultivated pepper $P$. nigrum $L$. is not included, nor the stoloniferous subshrub $P$. sarmentosum Roxb. (India to Malesia; known to me for New Guinea from one collection only: LAE 72479, Gulf Province, nr Kerema River, $30 \mathrm{~m}$ ). The scrambling subshrub $P$. wilhelmense Chew ex P.Royen of Mt Wilhelm is not treated either - for a description see Van Royen (1982). However, the latter three species are included in 'Synopsis' and 'Spot Characters' below.

\section{CHARACTERS AND IDENTIFICATION}

\section{Habit, foliage}

The climbing pipers are generally recognized thus by collectors, but sometimes one of the shrubby species (Gardner 2003) is mistakenly labelled as a climber, and occasionally, a collection is said to be from 'an epiphytic bush'. With the possible exception of $P$. versteegii, the architecture of these plants is one of sterile orthotropic 'climbing' shoots (leaves with sheathing petiole and relatively broad blade), and axillary, plagiotropic 'fertile' shoots. The latter bear a succession of solitary, terminal, 
spicate inflorescences. Through outgrowth of the axillary bud at the ultimate node the inflorescence there soon takes on its characteristic 'leaf-opposed' position.

Herbarium specimens usually comprise the distal part of a fertile shoot, stipule-tipped, leafy and with inflorescences at various degrees of maturity. The stems (subterete, smooth to lineolate in most species, weakly ridged in a few) of such specimens are referred to here as having 'fertile-shoot internodes'. That is, the stated dimension (diam) of the stem does not apply to the lower, more robust and often leafless parts of the fertile shoot. Similarly, the size and venation etc. of the leaf blade is described for mature leaves of the distal part of the fertile shoot.

The descriptions of the venation rely on being able to consistently distinguish the 'main lateral nerves' from the one to several weaker pairs of nerves that arise at the very base of the blade. Essentially, the latter have a looping course at least in the blades' distal half, and are obscure in a specimen sighted at arms-length. In 'palmately-nerved' (also called 'basally nerved' or '...-plinerved') species, such as $P$. arfakianum and $P$. macropiper s.str., the main nerves all arise at the base of the blade, the uppermost ones there being confluent with the midrib for only a few millimetres.

Hairiness of the foliage and newest growth of these plants is a rather variable feature. In mainly glabrous species, such as $P$. abbreviatum, $P$. interruptum and $P$. mestonii, indumented specimens are not especially uncommon, and often seemingly glabrous specimens will be found to have a few hairs on the stipule and in the petiole channel ( $P$. subcanirameum, however, is entirely glabrous). The size and form of the hairs mostly does not vary in a taxonomically useful way: the larger flexuose hairs, often forming a bristly or villous covering, are multicellular, and the smallest patent hairs might be unicellular, but all kinds of intermediate-sized hairs seem to exist too. The exception here is $P$. macropiper, where minute dendritic hairs occur on some specimens, and where a new large-leaved variety has a unique indument of long hairs scattered through much shorter ones.

Small reddish surficial glands $(0.05 \mathrm{~mm}$ diam) and larger pale silver-coloured 'glands' are variously found on both surfaces of the leaf blade. The latter type is actually the exudate from a small central secretory cell (Huber 1987), and it sometimes detaches as a subcircular flattened scale of c. $0.1 \mathrm{~mm}$ diam.

Reddish mottling of the blade, due to substances in the hypodermis, is usual in P. celtidiforme (Gardner 2006: 573, f. 4).

\section{Fertile parts}

As in previous studies (Gardner 2003, 2006, 2010) reliable characters for identification are found mostly in the female flowers and fruit. The size of the ripe infructescence, the shape of the individual fruitlets and their degree of 'concrescence' (fusion with one another and with the rachis), the shape and diameter of the bract-heads, and especially the nature and size of the stigmas, are all valuable. Piper decumanum and several other species usually have stigmas with a '2-lipped' character, but mostly the 3(-7) stigmas are grouped in a flat to reflexed rosette. This may be sessile or shortly raised on a tapering or columnar style. The stigmas may be papillose (most species) or linear-lanceolate and nearly smooth $(P$. celtidiforme and $P$. versteegii).

Features such as the degree of concrescence, bract size, and nature of the stigma, change little between flowering and fruiting, so the descriptive information given for the infructescence can in these respects be applied to flowering material too. For the purposes of identification then it is fortunate that the fruiting spikes, being so conspicuous, are so often collected; the downside is that providing good descriptions of the male parts becomes just that much more difficult. For example, in the two most common species discussed here, $P$. macropiper and $P$. mestonii, the proportion of male collections is only about 1 in 10, and, only some of them are at full anthesis.

Except for $P$. celtidiforme, where the anther locules are separated, the size of the anthers is stated here as a diameter - this is a maximum, the larger anthers usually being somewhat elongated along the axis of the spike. Whether or not the anther at flowering is exserted above the bract-heads seems likely to be a valuable taxonomic character. Exserted anthers generally dehisce by a pair of lateral (vertical to angled) slits, while those that dehisce at or just below bract level have a more or less continuous 'apical' (sometimes termed 'crescentic') slit over the top of the anther.

Immature anthers have a tendency to dehisce during specimen preparation. Collectors could help by closely describing the floral details of any male specimens they gather.

Photographs of specimens of New Guinea species (and the Philippines type of $P$. lessertianum) are given in Fig. 1, 3, 5, 8. Five species $(P$. bosnicanum, $P$. celtidiforme, $P$. fragile, $P$. insectifugum, $P$. interruptum) have previously been illustrated in this way (Gardner 2010). The leaves and inflorescences of $P$. arfakianum, P. subcanirameum, P. macropipers.I., P. mestonii and $P$. versteegii are shown in Fig. 2, 6, 7. Miscellaneous details are shown in Fig. 4.

Distinctions between the species accepted here are given below in 'Synopsis' and 'Spot Characters'. Information there and elsewhere applies, unless otherwise stated, just to dried material of fertile shoots.

\section{SYNOPSIS}

A. Fruitlets largely concrescent; infructescence less than c. $0.7 \mathrm{~cm}$ diam . P. abbreviatum, fragile, subcanirameum

AA. Fruitlets largely concrescent; infructescence c. 0.7-2.0 $\mathrm{cm}$ diam ... P. betle, majusculum, mestonii, versteegii

AAA. Fruitlets free at least in their upper two-thirds

B. Fruitlets subglobose, c. 1-3 mm diam, sometimes slightly sunk into/fused with rachis. ........P. arfakianum, $\ldots \ldots \ldots$ insectifugum, sarmentosum, wilhelmense, ........... subcanirameum [as an abnormality?]

BB. Fruitlets ellipsoid to cylindrical, relatively small (c. 1-2 $\mathrm{mm}$ diam), sessile, crowded ..... P. cf. amboinense, . celtidiforme, decumanum, lessertianum, macropiper

BBB. Fruitlets ellipsoid to ovoid or subglobose, relatively large (more than $3 \mathrm{~mm}$ diam) ... . P. bosnicanum, caninum, $\ldots \ldots \ldots \ldots \ldots$ interruptum, nigrum

\section{SPOT CHARACTERS}

( ) Of sporadic occurrence in the species.

* Character varies between named taxa of species-complex.

- See under P. lessertianum and P. macropiper.

** See Incertae Sedis.

\section{Petiole}

Ant-sac at apex: cf. amboinense **

More than 0.2 times as long as blade: (abbreviatum), fragile, (mestonii), versteegii

\section{Leaf blade}

More than $20 \mathrm{~cm}$ long: cf. amboinense ${ }^{* *}$, decumanum, (lessertianum $\left.^{\star}\right)$, (macropiper), (majusculum), (mestonii), (versteegii) Less than $3 \mathrm{~cm}$ wide: (arfakianum), (abbreviatum), (caninum), (macropiper)

Drying greyish, silvery glands usually evident: bosnicanum, caninum, interruptum 
Glabrous or nearly so: abbreviatum, bosnicanum, (celtidiforme), decumanum, insectifugum, interruptum, mestonii, subcanirameum, versteegii

Minutely pubescent (hairs that resemble cystoliths) near base below: betle

Base with unilateral lobule c. $2 \mathrm{~mm}$ diam: macropiper

Stomata pustulate: decumanum

Reddish mottles (10) on blade above and below: (abbreviatum), celtidiforme, (mestonii)

Nerves strictly basal: arfakianum, bosnicanum, macropiper ${ }^{*}$

\section{Male inflorescence (bisexual in P. nigrum)}

Peduncle about as long as spike or longer: lessertianum

Spike greater than $15 \mathrm{~cm}$ long: decumanum, insectifugum, (interruptum), (lessertianum), (macropiper), majusculum

Bracts sessile, suborbicular, c. $0.5 \mathrm{~mm}$ diam, only free at margins: caninum

Bracts sessile, suborbicular, 1-2 mm diam, only free at margins: bosnicanum

Bracts sessile, elongate, $2-4 \mathrm{~mm}$ long, free only at margins: interruptum

Bracts sessile, elongate, 2-4 mm long, free only at distal margin and forming a low cup there against base of ovary: nigrum

Anther very small (c. $0.2 \mathrm{~mm}$ diam), well-exserted on a slender filament, dehiscing laterally: caninum, versteegii

Anther c. $0.35 \mathrm{~mm}$ diam, well-exserted on a stout fleshy filament, dehiscing laterally: mestonii

Anther locules lateral, separated by and greatly exceeded by the subglobosely swollen connective: celtidiforme

\section{Infructescence}

Peduncle about as long as spike or longer: abbreviatum, (arfakianum), (betle), (bosnicanum), fragile, lessertianum

Spike less than $2 \mathrm{~cm}$ long: abbreviatum, (arfakianum), bosnicanum, fragile

Spike more than $15 \mathrm{~cm}$ long: decumanum, interruptum, (macropiper), majusculum

Style conspicuous, 1-2 mm long, giving fruit a subspinose character: mestonii, versteegii

Surface appressed brown-hairy between ovary tops: betle, majusculum

Stigmas ovoid-oblong, minute (together usually less than 0.35 $\mathrm{mm}$ diam), sparsely long-papillose: macropiper

Stigmas very narrowly ellipsoid-triangular, non-papillose, fragile: celtidiforme, versteegii

Fruitlets almost sessile, subglobose to shortly oblong, c. 3-4 $\mathrm{mm}$ diam, smooth or irregularly rugose: interruptum, nigrum

Fruitlets on a stipe less than $1 \mathrm{~mm}$ long, ovoid, c. 8 by $5 \mathrm{~mm}$, sometimes (when fully ripe?) severally-ridged: bosnicanum

Fruitlets long-stipitate, c. 3-4 mm diam: caninum

\section{Piper abbreviatum Opiz - Fig. 1a}

Piper abbreviatum Opiz (1828) 157; Quisumb. (1930) 59, pl. 20; Chew (1972) 1; (2003) 14; R.O.Gardner (2006) 579; (2010) 4. - Type: Haenke s.n. (holo PR n.v.), Luzon.

Distribution - Borneo, Philippine Is., Java, Celebes, Molucca Is., New Guinea, Solomon Is.; Australia (?).

Habitat \& Ecology — In forest, 0-500(-1650?) m altitude.

Notes - Recognized especially by its chartaceous, symmetrically ovate leaves, and short, stout, fully concrescent fruits. The leaves are generally glabrous but there may be a few slender, pale, patent hairs on the stipule, petiole and nerves below. A denser bristly to subvillous indument is seen in a number of specimens from West New Guinea, e.g. BW 7367, Vogelkop Peninsula.

The species seems to be uncommon in the Bismarck Archipelago. It is absent from the Highlands Region, and I am sure of only one New Guinea collection made from above c. 500 m: LAE 58792, New Britain, Mengen Massif, $900 \mathrm{~m}$. (Another collection, NGF 8485 (Morobe District, Skindewai, c. 1650 m), may be $P$. abbreviatum - its inflorescences are too young to be informative - but its $94.5 \mathrm{~cm}$ leaves seem too large for it to be credible that the stated altitude is correct).

The New Guinea plants are not nearly as conspicuously redglandular as those from the Philippines.

Borneo is included in the species' range solely because of the citations of Quisumbing (1930: 62) and Beaman \& Anderson (2004: 253).

A recently described species $P$. fungiforme (Spokes 2007: 234, 457 ), endemic to northern Queensland, resembles $P$. abbreviatum in some respects, notably in its short, fully concrescent fruits (as illustrated by Cooper 1994: 223, under the tag-name Piper sp. 'Leo Creek'). It is puzzling though that males are said to have their anther locules separated by a swollen connective, just as in $P$. celtidiforme. An re-examination of $P$. fungiforme needs to be undertaken to resolve whether it might represent a mixture.

\section{Piper arfakianum C.DC. - Fig. 1c, 2a-i; Map 1}

Piper arfakianum C.DC. (1917) 127; Chew (2003) 15. - Type: Gibbs 5525 (iso K, L n.v.), Arfak Mts, Angi Lake, [c. 1800 m].

Piper pilosulinodum C.DC. (1917) 128; Chew (2003) 15. - Type: Gibbs 5624 (holo BM; iso K n.v.), Arfak Mts, Koebre Ridge.

Fertile-shoot internodes c. $2 \mathrm{~mm}$ diam, nearly smooth. Vegetative parts (at least, stipule, newest internodes and petiole) with patent pale to mid-brown bristly-flexuose hairs to c. $1 \mathrm{~mm}$ long. Stipule to c. $1 \mathrm{~cm}$ long. Leaf blade chartaceous to subcoriaceous, ovate (or elliptic-oblong), $4-7(-10)$ by $1.5-4.5 \mathrm{~cm}$; base symmetrical, usually shortly cordate to rounded, subequal at petiole and usually shortly incurved there, apex long-acuminate;

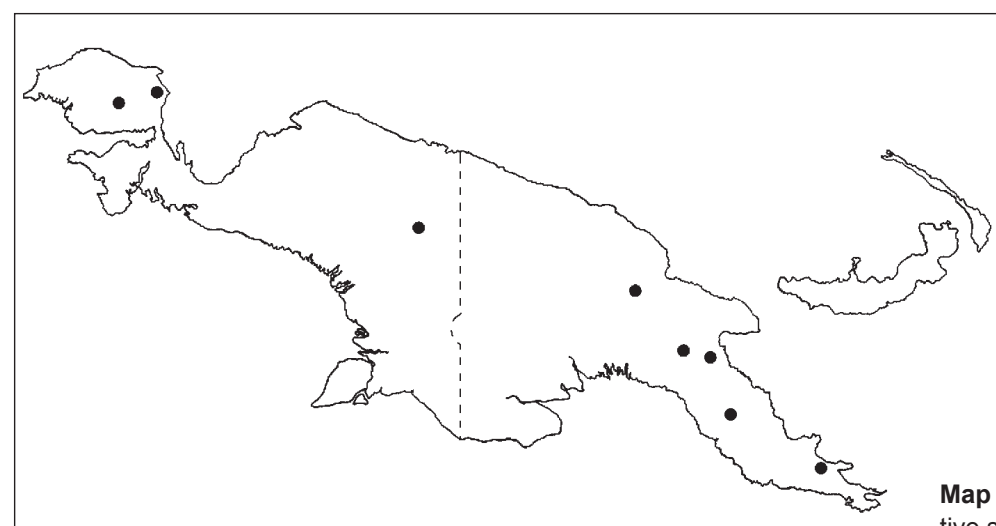

Map 1 Distribution of Piper arfakianum C.DC. in New Guinea. Representative specimens. 

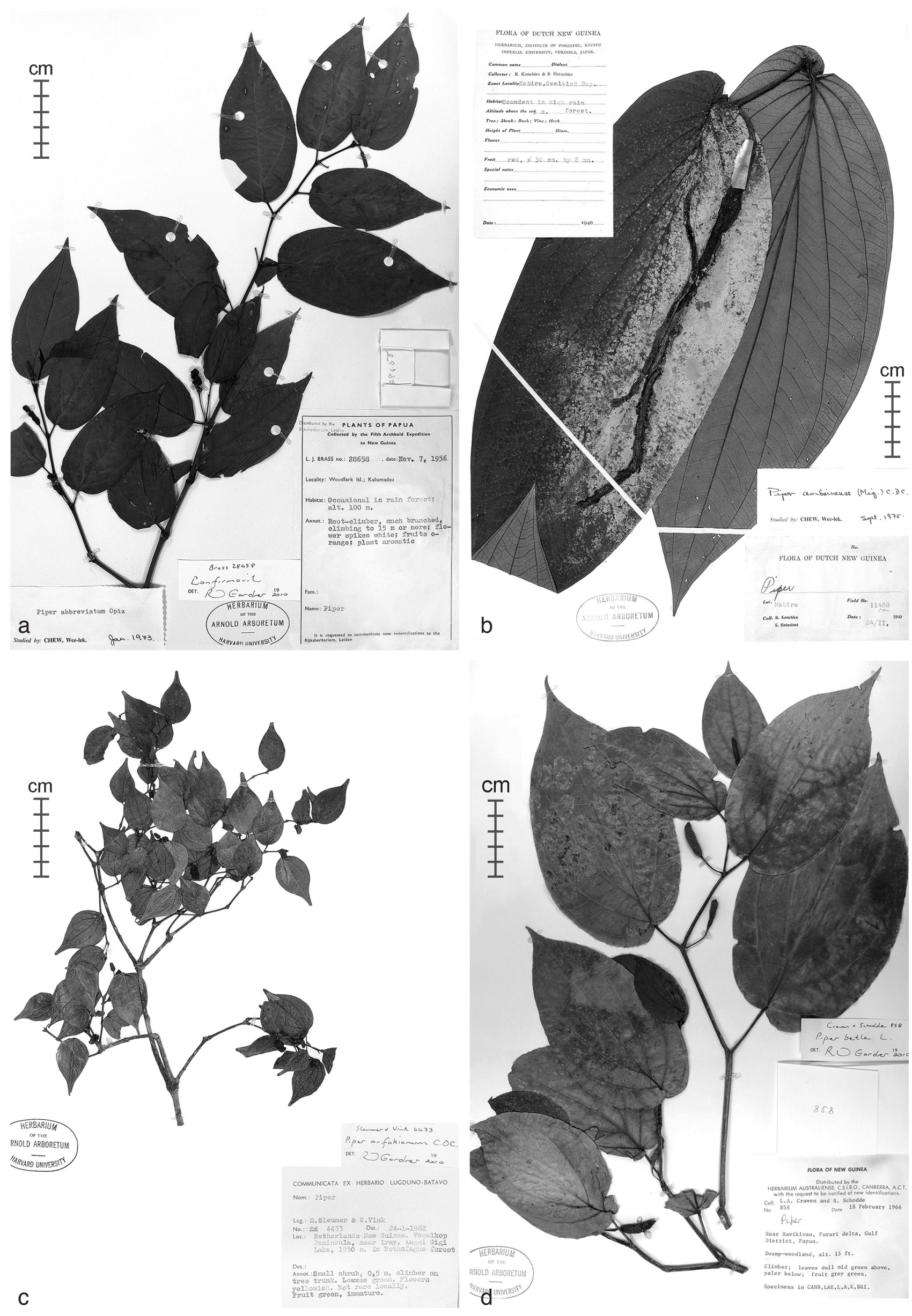

Fig. 1 Specimens of Piper species. - a. P. abbreviatum Opiz. - b. P. cf. amboinense (Miq.) C.DC. - c. P. arfakianum C.DC. - d. P. betle L. (a: Brass 28658; b: Kanehira \& Hatusima 11500; c: Sleumer \& Vink 4433; d: Craven \& Schodde 858, all A). 

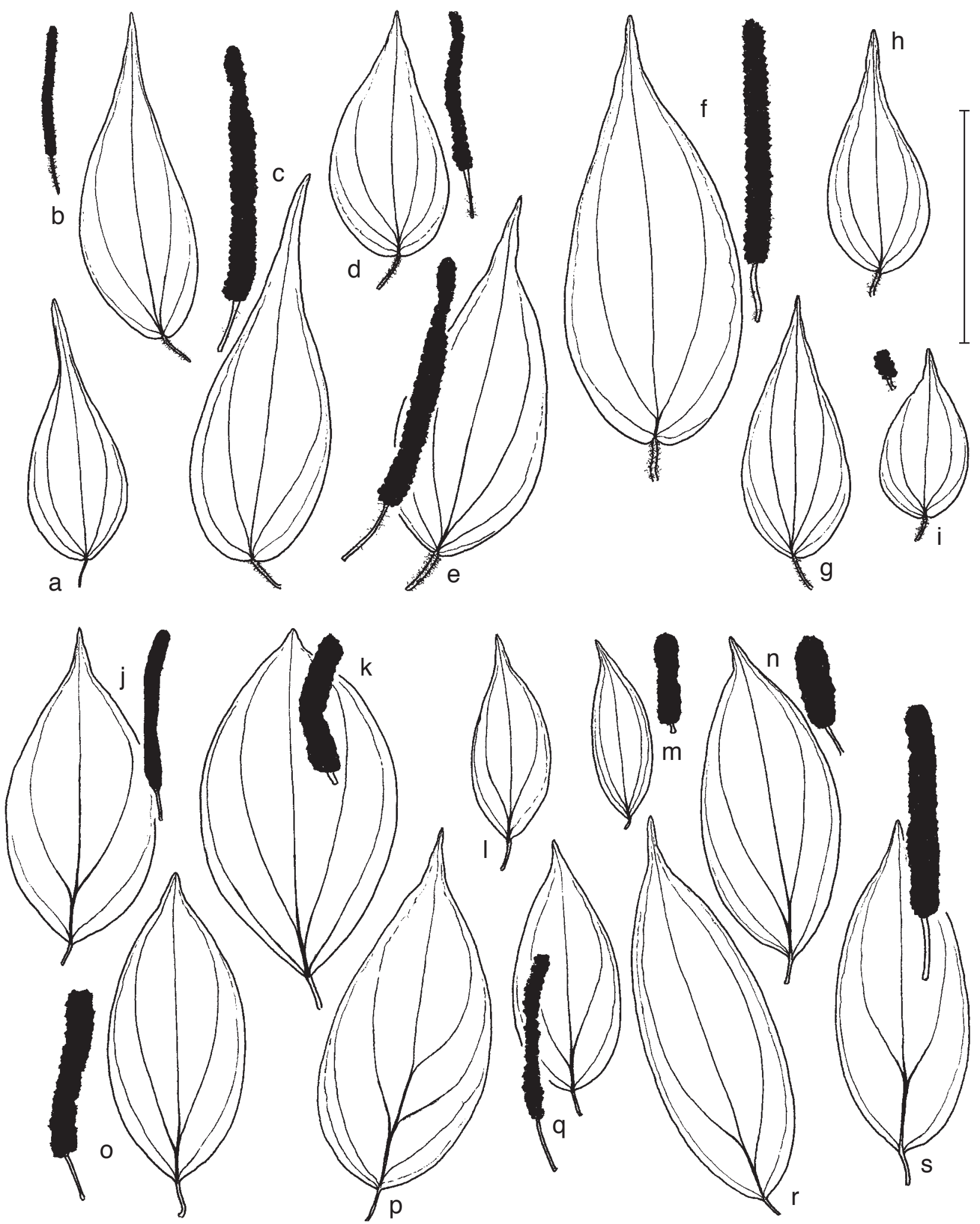

Fig. 2 Piper species. Fertile-shoot leaves and female inflorescence ('infr.'), immature infructescence ('infl/fr') or ripe infructescence ('infr.'). — a-i: P. arfakianum C.DC.; a. Brass 5029, Mt Tafa 2400 m, infl.; b. Brass 22534, Mt Dayman 2200 m, infl./fr.; c. Brass 22729 , Mt Dayman 2150 m, infr.; d. Kanehira \& Hatusima 13708, Angi 2200 m; e. Kostermans 2382, Angi Lake, 1800 m; f. LAE 60357, Mt Kaindi 2057 m, infr.; g. NGF 23627, Mt Kaindi 2300 m, h. NGF 30867 , Mt Kaindi 2150 m, infr.; i. Sleumer \& Vink 4433, Angi Lake 1950 m, infr. - j-s: P. subcanirameum C.DC.; j. Clemens 11215 p.p., Matap, Morobe Prov. c. 1600 m, infl/ fr.; k. Durand \& Nelson 146 (HUH herb. Gray), Mt Kaindi 2650 m, infr.; I. LAE 57084, lalibu 2515 m; m. NGF 19985, Edie Creek 2950 m, infr.; n. NGF 24994, lalibu 2000 m, infr.; o. NGF 30885, Edie Creek 2050 m, infr.; p. Schodde 1861, Mt Giluwe 3050 m; q. Takeuchi 5756 , Mt Wilhelm 2800 m, infl/fr.; r. Takeuchi 10702 (BRIT), Bismarck Range 2040 m; s. Takeuchi 20136, Porgera 2900 m, infr. (all from A except as noted). — Scale bar = $5 \mathrm{~cm}$. 
main lateral nerves 1-2 pairs, basal, narrowly prominent above; surfaces of blade sometimes red-glandular. Petiole $0.5-1.5 \mathrm{~cm}$ long, usually c. $1 / 6$ as long as blade. Male inflorescence not seen. Infructescence a spike c. $4-8 \mathrm{~cm}$ long, c. $0.5 \mathrm{~cm}$ diam, on a peduncle c. 1-2 cm long; rachis sparsely hirsute, bracts subsessile, glabrous to villous, bract-heads $0.5-1.3 \mathrm{~mm}$ diam, held at or just below apex of fruitlets. Fruitlets free, 1.2-2 mm diam, broadly rounded to flattened above but usually beaked by a stout style c. $0.25 \mathrm{~mm}$ long; stigmas 3 , broadly oblong, together c. $0.35-0.5 \mathrm{~mm}$ diam.

Distribution - New Guinea: Arfak Mts to Milne Bay Province. Habitat \& Ecology — Small climber or scrambler in montane moss forest, ridge thickets, and Nothofagus-dominated forest; c. $1900-2900 \mathrm{~m}$ altitude.

Notes - This species seems to be an uncommon one. I accept twelve of the thirteen extra-typical collections listed by Chew (2003: 16). They are mainly from Papua New Guinea, and I cannot add any new localities there or for the island as a whole. With respect to the thirteenth listing, Schodde 1556, I place this in P. macropiper (Fig. 6j).

Recognized by its small to medium-sized, ovate-triangular, long-acuminate leaves, which are usually coarsely bristly on the petiole and venation below. The major nerves all depart the midrib from 0-5 $\mathrm{mm}$ above the blade base, and the blade's basal margins are usually shortly incurved before the midrib channel is reached.

These features help distinguish the species from $P$. subcanirameum (shortly acuminate apex, glabrous, nerves departing from up to $1.5 \mathrm{~cm}$ from petiole base, blade margins decurrent down into sides of petiole). Both species have rather coriaceous and glossy leaves but there is a textural difference: in $P$. arfakianum the lesser venation is seldom as prominent above as it is in P. subcanirameum. Possibly the leaves of the former are, in life, relatively fleshy, but label-notes are inadequate on this point.

Material from the western part of the island has consistently smaller leaf blades (to c. $62.5 \mathrm{~cm}$ ) than those from Mt Kaindi and further eastwards.

Kostermans 2382, from the type locality, differs in its leaves being appressed-villous above and below.

Chew (2003) saw isotypes of P. pilosulinodum C.DC. and found them not to differ significantly from the present species. Having seen Van Royen \& Sleumer 7456 (Tamrau Mts, Mt Nettoti, CANB), said by Chew (2003: 15) to be a good match for the $P$. pilosulinodum types, I agree.

\section{Piper betle L. - Fig. 1d}

Piper betle L. (1753) 28; Quisumb. (1930) 85; R.O.Gardner (2006) 579; (2010) 8. - Type: Herb. Hermann 3: 32, 4: 9 (BM n.v.).

Distribution - Widely cultivated in Asia, Malesia, Micronesia, and in Melanesia east to Fiji.

Habitat \& Ecology — In gardens and persisting after cultivation, also naturalized; to c. $750 \mathrm{~m}$ altitude.

Notes - If the distinctive fruits are not present this species might be confused with $P$. caninum or $P$. interruptum, but its leaves tend to dry brownish rather than grey- or olive-brown and do not have large silvery glands. It almost always lacks long hairs, but near the base below (sometimes across both surfaces, best seen on new leaves) there is a scattering of minute $(0.05 \mathrm{~mm}$ long) appressed hairs.

Labels for New Guinea specimens of $P$. betle are generally unclear as to naturalization status. However, for the Bismarck Archipelago Peekel (1984: 124) says: "Everywhere wild in scrub ...".
Quisumbing (1930: pl. 42 (8)) described the stamen of $P$. betle as having a short stout filament c. $0.6-1 \mathrm{~mm}$ diam, with the two rather large anther locules colinear at the filament apex. Dehiscence takes place at or just below the bract-heads, and is by a continuous apical slit. As in other regions, female spikes can also bear stamens, e.g. in Darbyshire 1018.

\section{Piper bosnicanum C.DC.}

Piper bosnicanum C.DC. (1917) 207; Chew (2003) 17; R.O.Gardner (2010) 8. - Type: Gibbs 6277 (holo K; iso L n.v.), West New Guinea, Schouten Islands, Wiak, Bosnik.

Distribution - New Guinea, Solomon Is.

Habitat \& Ecology — In forest, to $400(-750)$ m altitude.

Notes - Recognized by its symmetrical, subcoriaceous, greyish, glabrous leaves that may be conspicuously silverglandular (as in $P$. caninum and $P$. interruptum), and especially, by the very short fruiting spike and large ovoid fruitlets.

Of male material from New Guinea I have seen only Docters van Leeuwen 11202 and Kanehira \& Hatusima 12103. They contrast with three male Solomon Is. collections in having relatively large stamens, and in these being paired rather than solitary (Gardner 2010: 8). Also, the leaf and the female spike tend to be larger in the Solomons, and possibly the fruitlets are larger there too, being, according to Chew (2003: 17), "c. $106 \mathrm{~mm}$ ". The basal leaf nervation, solitary anther (sometimes) and short female spike with large free fruitlets, give this plant a resemblance to $P$. quinqueangulatum Miq. ( $P$. korthalsii Miq.) of Borneo, Java and the Philippine Is. The latter, however, tends to dry more intensely orange-brown and its stems are more strongly ridged.

\section{Piper caninum Blume - Fig. 3a}

Piper caninum Blume (1826) 214; Quisumb. (1930) 120; Chew (1972) 5; R.O.Gardner (2006) 580; Spokes (2007) 239; R.O.Gardner (2010) 8. Type: Blume s.n. (holo L n.v.), Java.

Distribution - Western Malesia to the Solomon Is. and northeastern Australia.

Habitat \& Ecology — In forest, 0-500(-1600) m altitude.

Notes - Recognized by its chartaceous, greyish to olivebrown leaves which usually have a light cover of short pale bristly hairs. Rarely, the indument is subvillous (Streimann 8368 , Morobe Province, near Lae, $250 \mathrm{~m}$ ). Because of the similarity of leaf shape, texture, glandularity and nervation in $P$. caninum and $P$. interruptum, and because of the variability of the latter's indument, sterile specimens can be hard to place as one rather than the other of these two species.

The two highest-altitude specimens I have seen are both from 1600 m: Brass 24814, Milne Bay Province, Goodenough I.; NGF 37258, Western Highlands, Kopiango.

Van Royen (1982: 1269, f. 403) incorrectly described P. caninum as reaching "the upper subalpine shrubberies [at] $3290 \mathrm{~m}$ ". This altitude, and his f. 403, are based just on Vink 17365, which belongs to $P$. rodatzii of the $P$. macropiper species-complex.

Johns et al. (2006: 401) cite a Kloss specimen collected from "Camp IX-XIII" [c. 1700-3150 m] on Mt Jaya (Carstenz). I have not been able to check this specimen at BM, and regard even $1700 \mathrm{~m}$ as an anomalously high altitude.

The leaf blades of Hoogland \& Craven 10805 (East Sepik Province, Hunstein River, c. $150 \mathrm{~m}$ ) measure only 7 by $2 \mathrm{~cm}$. With this exception, and even at altitudes above $500 \mathrm{~m}$, narrowleaved plants seem not to occur in New Guinea. This contrasts greatly with the situation in the Philippines (Gardner 2006). 

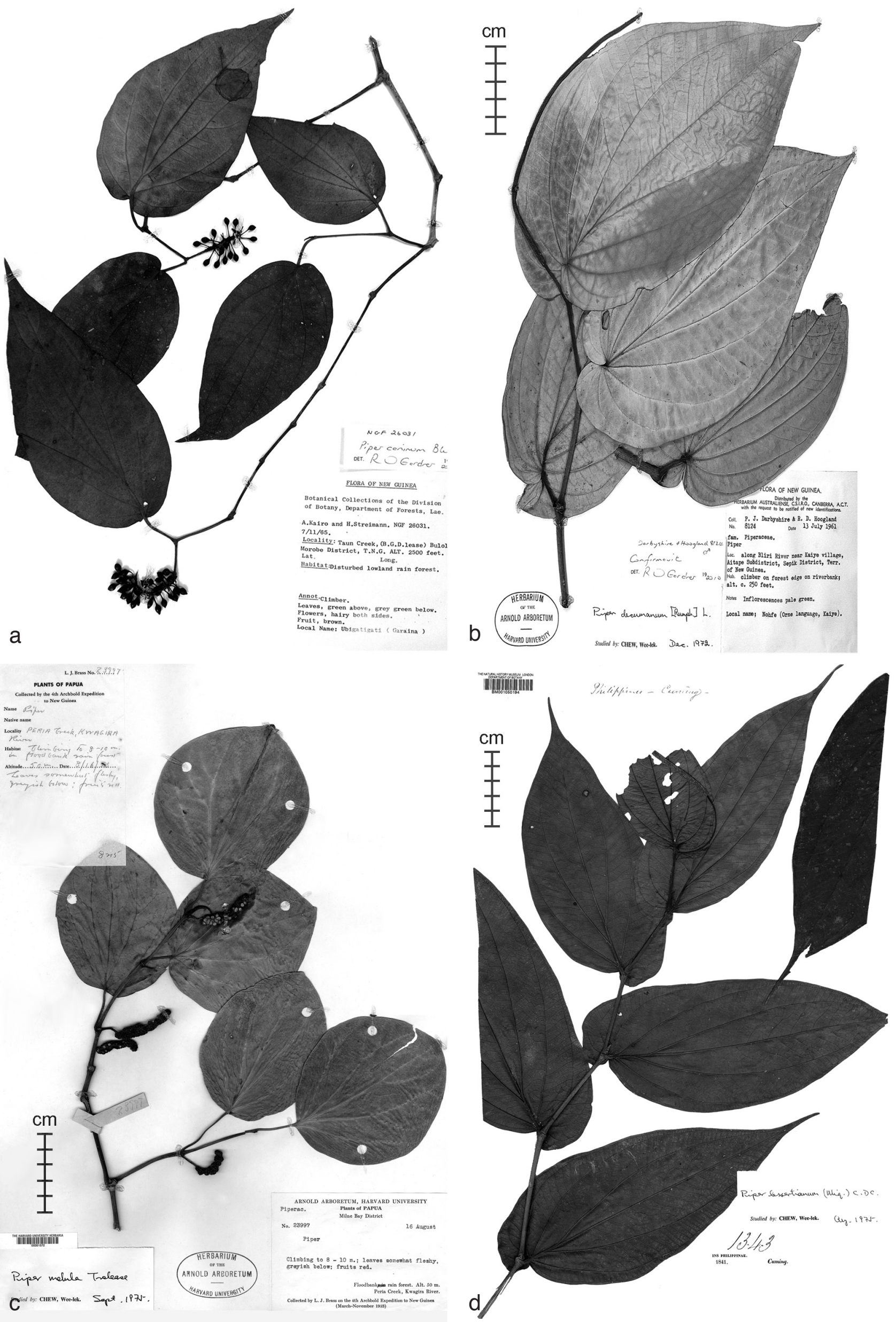

Fig. 3 Specimens of Piper species. - a. P. caninum Blume. - b. P. decumanum L. - c. P. insectifugum Seem. - d. P. lessertianum C.DC. (a: NGF 26031, A; b: Darbyshire \& Hoogland 8124, A; c: Brass 23997, A; d: Cuming 1343, BM). 

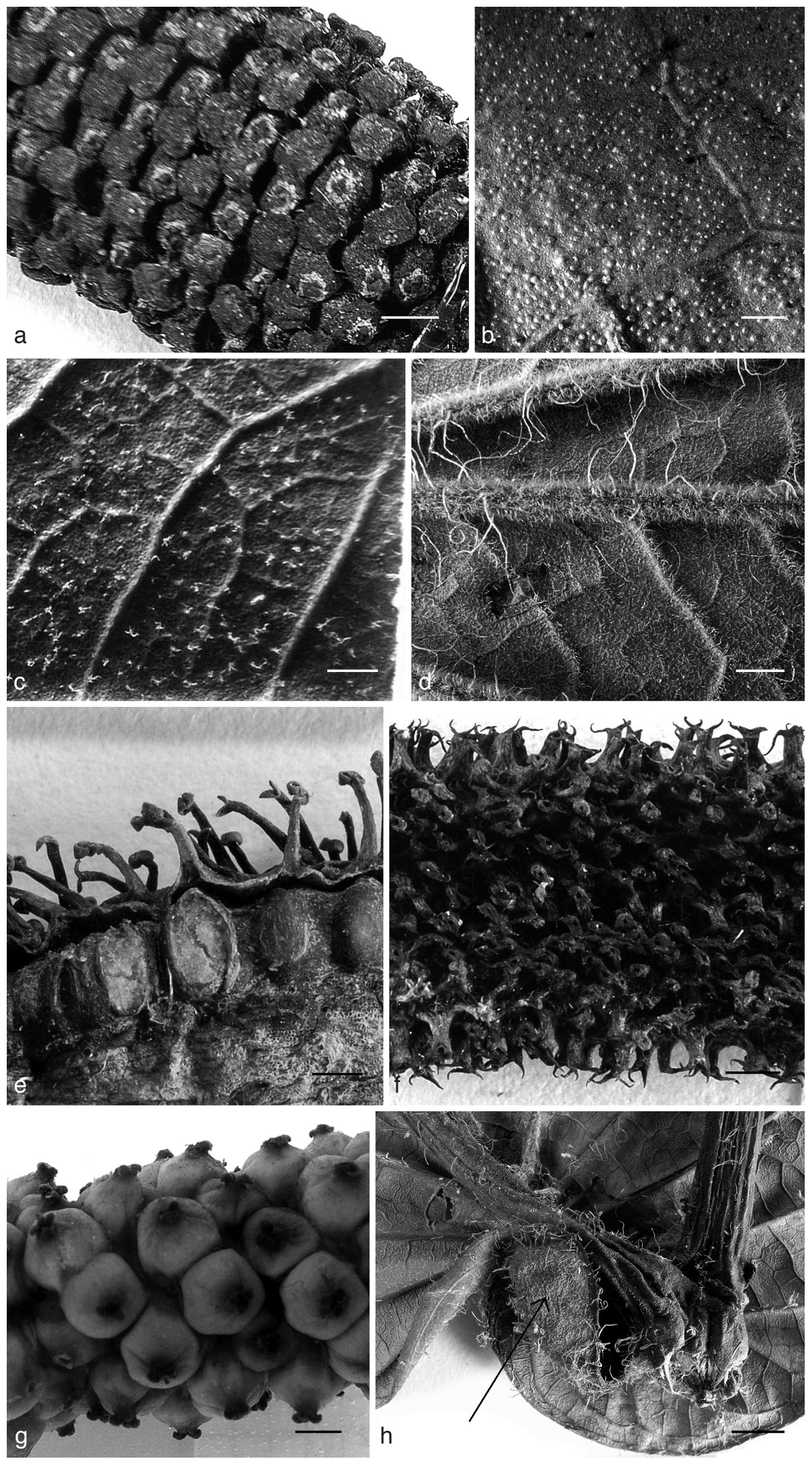
Three collections have leaves that are unusually coriaceous and glossy: Brass 24814 (cited above); Clemens 4520, Morobe Province, Ogeramnang; NGF 20253, Central Province, Woitape. They are not otherwise unusual.

Takeuchi 14166 (Morobe District, Guam River, c. 80 m, A) has a $30 \mathrm{~cm}$ long infructescence (in typical $P$. caninum, $8(-12) \mathrm{cm}$ ) and elongate bracts, as in $P$. interrruptum. But the densely hairy leaves suggest $P$. caninum, as do the hairy rachis and stipitate fruitlets. I therefore leave this collection undetermined.

\section{Piper celtidiforme Opiz - Fig. 4a}

Piper celtidiforme Opiz (1828) 152; Quisumb. (1930) 177, pl. 22; R.O.Gardner (2006) 580; (2010) 11. - Type: Haenke s.n. (holo PR n.v.), Luzon.

Piper seemannianum C.DC (1866) 164, syn. nov. - Type: Barclay 3515 (holo BM, image!), New Ireland.

Distribution — Philippine Is., New Guinea including Bismarck Archipelago, Solomon Is.; probably also Celebes.

Habitat \& Ecology — In forest, 0-2000(-c. 2700) m altitude.

Notes - Recognized by its chartaceous, ovate-oblong, nearly glabrous (never coarsely hairy), pinnate-veined leaves. The usual red subepidermal mottling is often sufficient to give the whole leaf a brownish red cast.

Male $P$. celtidiforme has uniquely-formed stamens (see 'Spot Characters'; Gardner 2006: f. 5). The female flowers are very distinctive too, their narrow, smooth-surfaced stigmas being seen elsewhere only in $P$. versteegii. These fragile structures are mostly lost as the fruit ripens and the fruitlet apex then just shows a ring of eroded tissue. Also, female specimens sometimes have a granulose papillosity around the base of the stigmas, making a whitish band conspicuous enough to be visible to the naked eye (Fig. 4a). Less frequently, the central third or so of a female's bract-heads also bears a patch of granulosity. The specimen NGF 34383 (West New Britain, Fulleborn Harbour, $50 \mathrm{~m}, \mathrm{~A}$ ) is unusual in having 4-6 very short, broadly ovate, strongly papillose stigmas. Also, the stigmas of Takeuchi 15243 (Morobe Province, Tabare (Tabili) River, sea level, A) have the usual narrow character but are also notably papillose. Neither though seems otherwise unusual for $P$. celtidiforme.

The occurrence on Celebes seems likely, since de Candolle (1923: 278) synonymized one of his names from there, $P$. sinkojan C.DC. (as 'P. sinkgian') with P. corylistachyon C.DC. of the Philippines, and the latter has, correctly I believe, been placed by Quisumbing (1930: 177) under P. celtidiforme. De Candolle never saw the PR holotype of $P$. celtidiforme - as the annotation-free photograph of Quisumbing (1930, pl. 22) proves - and in his 1923 account he treated the species just as a 'Eupipera non satis nota'.

For the Bismarck Archipelago Peekel (1984: 129) says, under $P$. singkojang [sic]: "Easily the most common species of pepper in the region; widespread on the trunks of forest trees. The red fruit-spikes, erect from horizontal twigs on the tree-trunks, are particularly conspicuous. Where the plants find little support, the stems and branches spread widely over the ground and the densely-set leaves form there a regular turf. The leaves of such plants are usually smaller and their bases deeply cordate or reniform".

\section{Piper decumanum L. - Fig. 3b, 4b}

Piper decumanum L. (1754) 19; Quisumb. (1930) 42; Chew (1972) 6; R.O Gardner 2006 (581). - Type: Rumph., Herb. Amb. 5 (1747) 45, t. 27

Distribution - Celebes, Molucca Is., Philippine Is., New Guinea (western part of island, also Sepik and Madang regions); possibly also Micronesia.

Habitat \& Ecology — In forest, to c. $500 \mathrm{~m}$ altitude.

Notes - This species is apparently uncommon in New Guinea, just as it is in the Philippines, where Quisumbing (1930: 42) saw only four collections, all from 'medium altitude'. The New Guinea specimens I know of - those I have seen myself, and others cited by Chew (1972: 7) - are from the northern side of the island, from the Vogelkop east to Madang Province (NGF 24752, near Aiome).

I have seen only a few specimens of the Micronesian (Palau Is.) taxon $P$. hosokawae Fosberg ( $P$. decumanum var. palauense Hosok.), none of which have mature infructescences. Their leaves, e.g. as in Takamatsu 1784 (B) are relatively small (c. 18 by $10 \mathrm{~cm}$ ) compared to those typical of Malesian P. decumanum but are not otherwise unusual. Fosberg \& Sachet (1975) do not mention anything distinctive about the female parts of $P$. hosokawae.

The stomata of $P$. decumanum leaf are borne singly on low pustules scattered across the blade underside (Fig. 4b).

\section{Piper fragile Benth.}

Piper fragile Benth. (1843) 234; Quisumb. (1930) 99; Chew (1972) 7; Fosberg \& Sachet (1975) 19; Peekel (1984) 203; R.O.Gardner (2006) 581; (2010) 11. - Type: Hinds s.n. (K n.v.), New Guinea.

Distribution — Molucca Is., Philippine Is., New Guinea (northern coast, also Milne Bay and Bismarck Archipelago), Solomon Is., Vanuatu, Micronesia.

Habitat \& Ecology - Coastal forest and scrub, mainly on limestone and coral sands, perhaps only to c. $100 \mathrm{~m}$ altitude.

Notes - De Candolle (1869: 336) based his $P$. barclayanum on a BM collection from the H.M.S. 'Sulphur' voyage: Barclay 4021 , island of Japen ('In ins. Tobia'), West New Guinea. He placed it at that time in his sect. Pothomorphe, which included taxa like P. peltatum L. and Macropiper spp. Subsequently, in his Candollea treatment (1923: 171), he placed it in sect. Macropiper. Smith (1975: 35) was unable to locate a type for $P$. barclayanum and commented that there was nothing in its description to suggest it was a Macropiper. He might have added that a New Guinea occurrence would be a notable regional range extension westwards from the Santa Cruz Is.

A sheet of Barclay 4021 (BM 000624274 , image!) has been found in the present study, but bears no De Candollean annotation. It represents $P$. fragile.

Piper fragile might be confused with $P$. abbreviatum, but its leaves are glabrous and thicker and tend to dry olive yellowish rather than dark grey. Also, its leaves (mainly just the climbingshoot ones) are subpeltate to peltate.

In New Guinea this species seems to occur just along the northern coasts and on the islands there. Fosberg \& Sachet (1975) say it is common in Micronesian lowland forests. Peekel

Fig. 4 Piper species, various features. - a. P. celtidiforme Opiz. Infructescence, showing ring of white papillae around base of stigmas. - b. P. decumanum L. Leaf underside, showing pustulate stomata. - c. P. macropiper Pennant s.str. Specimen from Morobe Province, leaf underside, showing dendritic hairs. - d. P. macropiper var. macrophylla R.O.Gardner. Leaf underside, showing indument of nerves near blade base. - e. P. mestonii F.M.Bailey. Infructescence, longitudinal section, showing coriaceous surface of the fused ovaries, long styles and '2-lipped' stigmas. $-\mathrm{f}$. $P$. versteegii C.DC. Infructescence, showing the long styles and very narrow stigmas. - g. P. subcanirameum C.DC. Infructescence (rehydrated), showing the mostly-free fruitlets. - h. $P$. cf. amboinense C.DC. Leaf base below, showing ant-sac (a: NGF 32677; b: Darbyshire \& Hoogland 8124; c: Takeuchi 4572; d: Takeuchi 8675; e: NGF 40944; f: Brass 7000; g: Takeuchi 5756, B; h: Kanehira \& Hatusima 11500; all from A except as noted). - Scale bars $=1 \mathrm{~mm}$. 
(1984: 129) describes it in the Bismarck Archipelago: "Frequent; climbing on tree-trunks and on coral rocks behind beaches. The natives gaily crown themselves with the decorative, often mottled, leaves".

\section{Piper insectifugum Seem. - Fig. 3c}

Piper insectifugum C.DC. ex Seemann (1868) 262; C.DC. (1869) 354; A.C.Sm. (1981) 61; R.O.Gardner (2010) 7. - Type: Seemann 569 (BM, $\mathrm{GH}, \mathrm{K})$, Viti Levu, 1860.

Piper austrocaledonicum C.DC. (1869) 346; Chew (2003) 16, syn. nov. Syntypes: Forster s.n. (BM n.v.), New Caledonia; Vieillard 1227 (GH n.v., P), New Caledonia.

Piper peekelii C.DC. (1922) 354; Peekel (1984) 129; Chew (2003) 16. Type: Peekel 322 (holo B), Neu-Mecklenburg [New Ireland].

Piper melula Trel. (1928) 148; Chew (2003) 20, syn. nov. - Type: Brass 1130 (holo A; iso BRI n.v.), Papua New Guinea, Vailala ['Vaitata'] River, Gulf Province.

Piper philippinum sensu Quisumb. (1930), non Miq. (1843-1844) 322.

Distribution - Taiwan, Philippine Is., New Guinea, Solomon Is., New Caledonia, Fiji and Samoa.

Habitat \& Ecology - In forest, near the sea or some way inland but at low altitude.

Notes - For P. insectifugum in New Guinea De Candolle (1925: 219) cited Riggenbach 16 [Mamberamo region] and Moskowski 16 [no locality given]. Chew (2003), under $P$. austrocaledonicum, cited two collections: Peekel 322 as in the synonymy above, and Schlechter 14381, 'Torricelli', BO. I have only seen Peekel 322, and can confirm its identity.

I have also seen some of the material maintained by Chew (2003) as P. melula and do not think this taxon differs from $P$. insectifugum in any important way (compare Fig. 3c with Gardner 2010: f. 6a, b). Chew (2003: 20) in the notes following his full description suggested that $P$. melula appeared "to be related to $P$. austrocaledonicum".

Piper insectifugum appears to be rare on the New Guinea mainland (I cannot add to the specimens listed by Chew (2003) under P. austrocaledonicum or P. melula). However, for the Bismarck Archipelago Peekel (1984: 129) says: "Common on the foreshore". It is in accordance with this observation that all (four) $P$. melula specimens cited by Chew (2003) come from coastal or low-altitude places. In particular, the type is from 'Hewa' on the Vailala River, a locality 3 days canoe travel inland from Ihu near the mouth of that river (Van Steenis-Kruseman 1950: 76).

Piper philippinum sensu Quisumbing and the very similar $P$. albidirameum C.DC. and P. magnaasanum C.DC. (Quisumbing 1930) are typified from Philippine Islands collections. Quisumbing's excellent descriptions and illustrations leave little doubt in my mind that these names are synonyms of one another, and also indicate (e.g., in the narrow male spikes and large, partly concrescent fruitlets with large stigmas), that these taxa are conspecific with $P$. insectifugum. The occurrence of sterile female floral structures in the flowers of $P$. philippinum (Quisumbing 1930, Gardner 2006) should not, I think, be decisive in keeping this apart from $P$. insectifugum, since the bisexual condition is known to occur sporadically at least in several other species, e.g., in $P$. betle and $P$. nigrum.

Quisumbing (1930: 112) thought the type of $P$. philippinum was the male collection Cuming 912, but Miquel simply mentioned this as possibly being conspecific with the female collection Cuming 1642 he was describing (Miquel 1843-1844, Gilbert \& Xia 1999). Miquel's statement that the female had free fruitlets 4-5 mm long means it cannot be placed in $P$. insectifugum, so this name still has priority for the taxon being considered here. The extension of the range of $P$. insectifugum to Taiwan is based on the occurrence there of $P$. kwashoense Hayata, the name used by Gilbert \& Xia (1999: 193) to replace P. philippinum sensu Quisumbing.

\section{Piper interruptum Opiz}

Piper interruptum Opiz (1828) 157; Quisumb. (1930) 154, pl. 21; R.O.Gardner (2006) 581; Spokes (2007) 237; R.O.Gardner (2010) 11. - Type: Haenke s.n. (holo PR n.v), Luzon.

Distribution - Taiwan, Philippine Is., New Guinea, Solomon Is., and possibly Vanuatu (Gardner 2006: 582); also Australia. Habitat \& Ecology — In forest, to c. 700(-1300) m altitude.

Notes - Two specimens have the anomalously high altitude of c. 1300 m: Carr 13458, Central Province, Boridi; NGF 29214, Eastern Highlands Province, Kassam Pass.

The leaves of New Guinean and Solomons specimens have a palmate-pinnate nervation, in contrast to the usual strictly palmate (basally nerved) condition in plants from the Philippines (Gardner 2006).

The taxon described under this name by Van Royen (1982) is P. bolanicum Schltr. ex R.O.Gardner, a montane shrub.

\section{Piper lessertianum C.DC. - Fig. 3d}

Piper lessertianum C.DC. (1866) 164; Quisumb. (1930) 36; Chew (2003) 17; R.O.Gardner (2006) 582. - Type: Cuming 1343 ('1342') (holo BM, image!), Luzon.

Chavica lessertiana Miq. (1843-1844) 270. - Type: Cuming 1343 (holo G n.v.).

Distribution — Philippine Is., Celebes (f. Chew 2003: 19), New Guinea, Solomon Is.

Habitat \& Ecology — In forest, perhaps from near sea level to c. $820 \mathrm{~m}$ altitude at least.

Notes - Chew (2003: 18) pointed out that the authority for $P$. lessertianum should be solely that of $\mathrm{C}$. de Candolle, who published the name without referring in any way to Chavica lessertiana Miq.

In my treatment of this species in the Philippines (Gardner 2006) I neglected to comment on the altitudinal variation there: lower-altitude specimens, and the type collection Cuming 1343 (no altitude stated in its protologue) have relatively large but narrow, deeply cordate-auriculate, shortly petiolate leaves, and the peduncles of their inflorescences (male or female) are much longer than the spikes themselves. Nor did I mention that Quisumbing (1930) placed at least some of the smaller-leaved, higher-altitude plants under other names, e.g., $P$. delicatum C.DC. and P. halconense C.DC.

Nevertheless, I believe that the uniformity of the fruitlets of all this material (free, sometimes with a short tapering stylar beak, c. $2 \times 1.2-1.8 \mathrm{~mm}$; stigmas $3(-4)$, together c. $0.5 \mathrm{~mm}$ diam) makes it reasonable to suppose that only one taxon is represented. Also, Chew (2003: 19) noted the extreme variability in leaf form, from elongate to broadly cordate, and pointed out that one collection, BW 8871 (West New Guinea) shows such variation 'on the same plant'.

I have not myself seen any $P$. lessertianum specimen from New Guinea that closely resembles the Philippines higher-altitude form. With respect to lower-altitude (elongate-leaved) plants, I have seen two such specimens, both cited by Chew (2003): NGF 28829 (Milne Bay District, nr Mayu I., $350 \mathrm{~m}$ ) and Pullen 5924 (Northern [Oro] Province, Sibium Range, c. 820 m). I therefore think it reasonable to accept the three other of his citations as belonging to this species: $B W 8871$, Wissel Lakes; Ijiri \& Niimura 674, Mapon District, Wati and NGF 24403, Morobe Province, Asubazo. I also include on my own cognizance the relevant part of the mixed sheet Kloss s.n., K, Mt Carstenz [Jaya], 'Camp I 700 feet, Nov.-Dec. 1913'. 

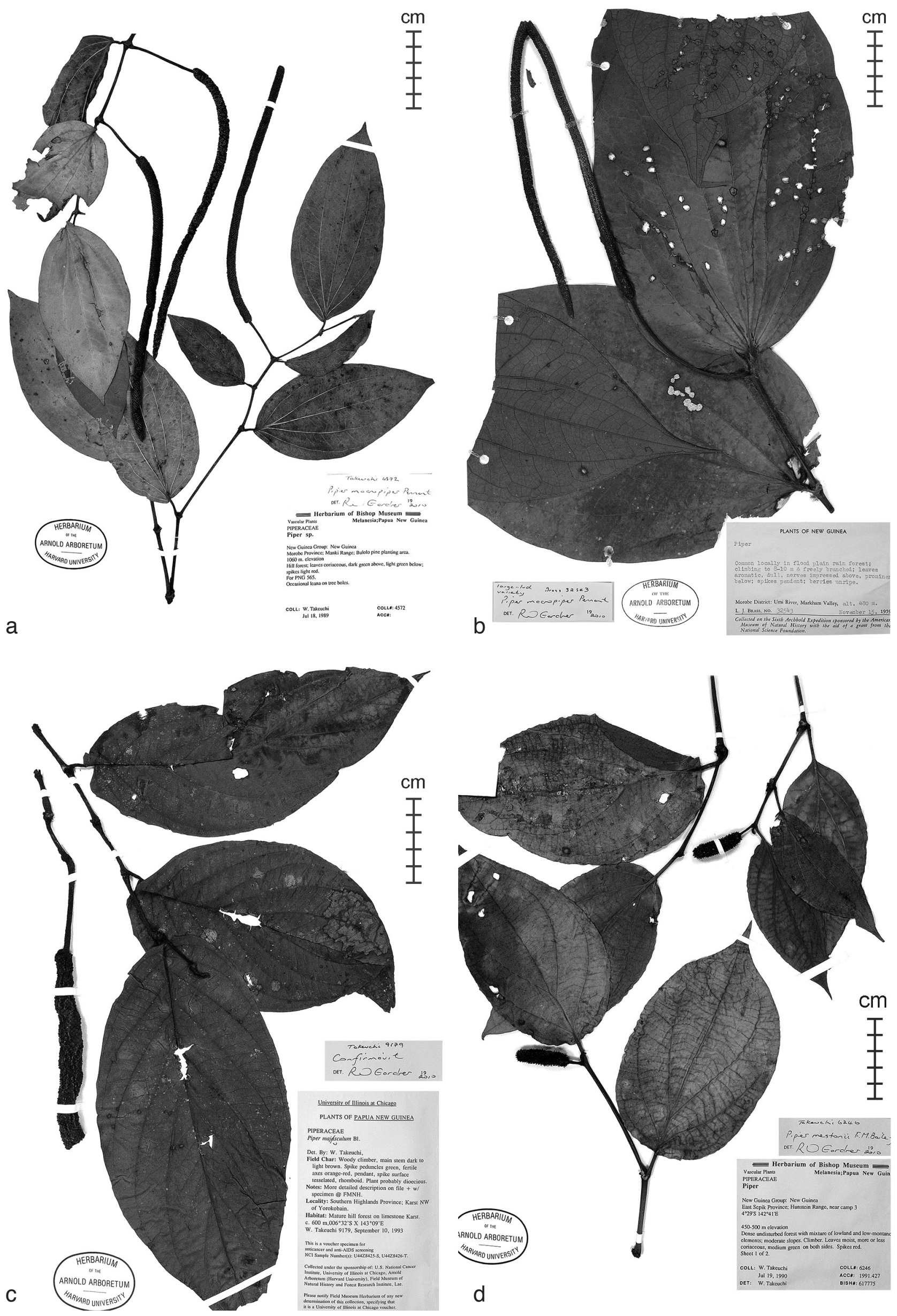

Fig. 5 Specimens of Piper species. - a. P. macropiper Pennant. - b. P. macropiper Pennant var. macrophylla R.O.Gardner. - c. P. majusculum Blume. d. P. mestonii F.M.Bailey (a: Takeuchi 4572; b: Brass 32543; c: Takeuchi 9179; d: Takeuchi 6246, all A). 


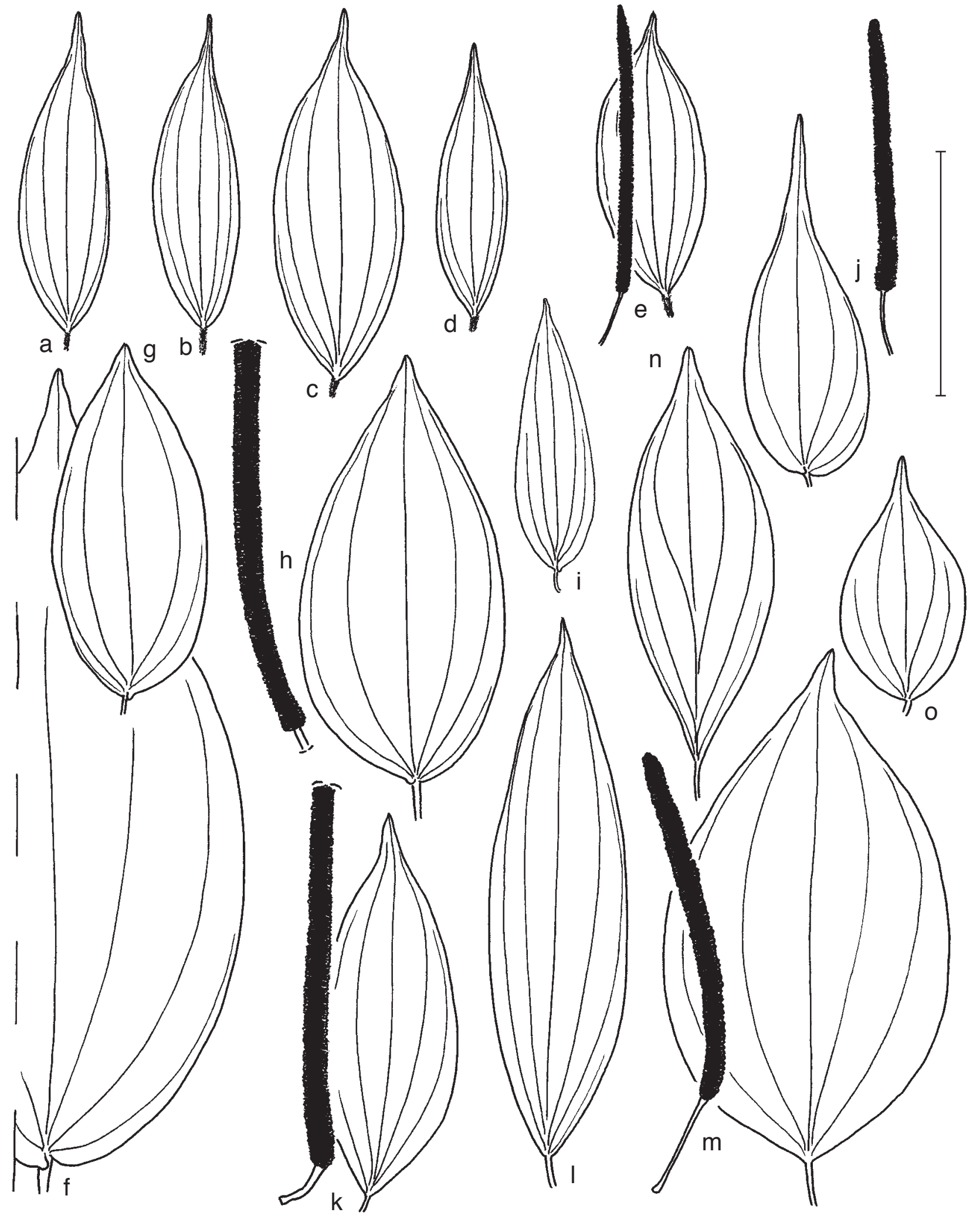

Fig. 6 Piper macropiper complex. Fertile-shoot leaves and ripe infructescences (shortened by half in h, k). - a-e: P. breviantherum C.DC.; a. Craven \& Schodde 1093, Aseki Patrol District 1600 m; b. Gardner 7068 (AK), Kaironk Valley 1700 m; c. Hoogland \& Pullen 6163, Mt Hagen Ra. 2550 m; d. Hoogland \& Schodde 6914, Yaki River 2450 m; e. Kalkman 5200, Mt Ambua 2650 m. - f-i: P. macropiper s.str.; f. Brass 13976, Idenberg R. 55 m; g. Brass 25216, Goodenough I. 150 m; h. Brass 31596, Okapa, Eastern Highlands 1950 m; i. Takeuchi 5337, Hunstein Ra.; j. Schodde 1556, Anga Valley 2000 m. — k, I. P. novoguineense Warb.; k. Gardner 9009 (AK), Kaironk Valley 2100 m; I. Pullen 411, Asaro-Mairifutica Divide 2600 m. — m-o. P. rodatzii K.Schum. \& Lauterb.; m. Brass 24658, Goodenough I. 1600 m; n. Brass 30479, Mt Wilhelm 2770 m; o. Takeuchi 20143, Porgera $2900 \mathrm{~m}$ (all from A except as noted). — Scale bar = 5 cm.

Chew (2003: 18) also synonymized three New Guinea-typified taxa with $P$. lessertianum. They are: Biro 32, B, "near Malanaku", type of $P$. biroi K.Schum. \& Lauterb.; Roemer 962, L n.v., Mt Hellwig, type of P. lineatipilum C.DC; Brass 1370, A, BRI n.v., Gulf District, Mowabula, type of $P$. viridibaccum Trel. I cannot confirm this synonymy, because of the complication outlined below.
Chew (2003) accepted as a species "closely similar" to P. lessertianum a larger-leaved plant, $P$. pseudamboinense C.DC. In addition to the type, which is from the Ramu River (see Incertae Sedis for locality, etc), he cited two collections, also from lowland forest in Morobe Province: NGF 25678, Buso River and Hartley 10564, Oomsis Creek. I have seen several similar collections from this part of New Guinea (LAE 70724, Takeuchi 5629, 5669, 
14024) and one from c. $100 \mathrm{~km}$ away (Platts-Mills 51, Madang Province, Adelbert Range, $650 \mathrm{~m}$ ). As well as cohering geographically these plants present a uniform appearance in their large (c. 25 by $13 \mathrm{~cm}$ ), chartaceous, palmate-pinnately nerved leaves. The three collections with mature fruit (Takeuchi 5629, 5669; Platts-Mills 51) have long-pedunculate female spikes composed of smallish, free, ovoid, shortly beaked fruitlets (Fig. 8a). A major point of difference with $P$. lessertianum is, as Chew (2003) has noted, the fruitlets' two-lipped stigmas.

However, the differences as outlined above are not applicable to male collections, nor to sterile ones with leaves of intermediate size, e.g., Takeuchi 14455, Bulili Ridge, Morobe Province, 215 m and Takeuchi 14828, Arawiri River, Morobe Province, $\mathrm{nr}$ sea level. Also, I have seen one Morobe Province specimen of intermediate leaf size (Takeuchi 14432, Tabili Creek, $100 \mathrm{~m}$ ) whose fruitlets have three small oblong stigmas as in P. lessertianum.

For the above reasons then $P$. lessertianum is maintained here to include $P$. pseudamboinense. However, for the convenience of those who might want to take the matter further, the 'List of Collections' indicates which plants fit a rigorous definition of P. pseudamboinense ("leaves greater than c. $20 \times 10 \mathrm{~cm}$; stigmas 2-lipped").

As mentioned above, Chew (2003) synonymized three New Guinea-typified names with $P$. lessertianum. I do not know whether any of those names might better fit P. pseudamboinense. For example, the protologue for $P$. viridibaccum (Trelease 1928) has reference to characteristics of both species: "leaf blades $15-17 \mathrm{~cm}$ long ... stigmas 2".

\section{Piper macropiper Pennant - Fig. 4c, d, 5a, b, 6a-o}

Piper macropiper Pennant (1800) 242; Merr. (1948) 191; Chew (1972) 10; Peekel (1984) 124; R.O.Gardner (2006) 582; Spokes (2007) 236; R.O. Gardner (2010) 12. - Type: Rumphius, Herb. Amb. 5 (1747) 46, t. 28, f. 1

Distribution - Taiwan, throughout Malesia, also Vanuatu, Micronesia, Australia, and the Pacific Ocean region (Wallis \& Futuna Is., Samoa).

Habitat — In forest, 0-2000(-c. 3300) m altitude.

Notes - As noted in the Introduction, the New Guinea plants under this name are treated here as a species-complex. The four major named variants are as follows. (For types and publication data see 'Incertae Sedis'. The 'List of Collections' indicates which specimens best fit the circumscriptions here). See Fig. 6 for the variation in leaf size and shape, etc. Additionally, a new large-leaved variety is described further below.

1. Piper macropiper s.str. - Leaves with a unilateral basal lobule, nerves basal or nearly so, glabrous or hirsute to villous; throughout New Guinea incl. Bismarck Archipelogo, 0-1500 $(-2500) \mathrm{m}$ altitude.

2. Piper breviantherum - Leaves relatively short and narrow, without a basal lobule, nerves basal or nearly so, indument usually sericeous; infructescence relatively slender $(6-9(-13)$ by $0.35 \mathrm{~cm}$; central part of New Guinea, from the Star Mts (West Sepik Province) to the Eastern Highlands and Morobe Provinces, (490-)2000-2500 (-c. 3000) m altitude.

3. Piper novoguineense - Leaves without a basal lobule, nervation usually palmate-pinnate (i.e., usually one or more nerves suprabasal), usually conspicuously red-glandular, glabrous; mainly in Morobe Province (absent from the Bismarck Archipelago and islands of the Milne Bay District), $\mathrm{c}$. 75-2800 m altitude.

4. Piper rodatzii - Leaves relatively broad, without a basal lobule, nervation palmate-pinnate (uppermost nerve from up to c. 1/3 way along midrib), chartaceous, glabrous; infructescence usually relatively short and stout (to c. 10(-14) by $0.7 \mathrm{~cm}$ ), bracts with red-brown hairs spreading from near top of bract-stalk for up to c. $0.4 \mathrm{~mm}$ beyond margin of head surface of bract-heads usually glaucous; throughout New Guinea, but apparently rare in the western half of island and in the Bismarck Archipelago and islands of the Milne Bay District, (100-)500-2500(-3290) m altitude.

These four variants, if interpreted strictly according to the given characters, take in much of the variation in this complex, but nevertheless a considerable number of specimens cannot be placed into one or the other. This is not to say that all kinds of intermediates occur: a basal lobule, for example, is never found in a rodatzii- or breviantherum-kind of leaf blade.

Another difficulty is that I have seen far too few specimens from West New Guinea to be sure that the last three taxa, all typified on Papuan New Guinea collections, properly represent the range of geographical variation on the island as a whole. For this reason especially, I am not willing to change their taxonomic status (say, to subspecies rank).

Piper macropiper in the strict sense is common in New Guinea up to c. $1500 \mathrm{~m}$, but above that one or other of the three variants seem to predominate. The four can certainly grow in the same general area - I have seen them thus in the Kaironk Valley, Schrader Range, between c. 1500 and 2500 m altitude.

Specimens of climbing pipers are sometimes labelled as 'epiphytes' or 'shrubs'. This is most often said about $P$. rodatziiI have seen more than a dozen such examples, including two of my own from the Kaironk Valley at 1700-2200 m: Gardner 7078, "low epiphyte on relict streamside-forest tree"; 9681, "bushy plant c. $1 \mathrm{~m}$ tall on open gully floor in primary forest, perhaps originally climbing ?". Similarly, the label of Grubb \& Edwards 187 (Fatima River, 2600 m) has: "Scrambler/climber up lower boles, or, apparently, independent shrub", and that of Takeuchi 10541 (Bismarck Range, c. 2400 m): "Epiphytic shrublet". Only a very few specimens elsewhere in the $P$. macropiper complex (e.g. P. breviantherum, LAE 65805 and $P$. macropiper s.str., Brass 13976) note such a habit.

Specimens with small dendritic hairs (Fig. 4c), these sometimes accompanied by a typical coarser indument, are from low to moderate altitude (to c. $1000 \mathrm{~m}$ ) in Morobe District, e.g. Clemens 1257, 1721, 7959, 10824, 40849, Hartley 9765, NGF 26030, Takeuchi 4572) with one from nearby East Sepik District ( $L A E$ 73630). All belong to P. macropiper s.str. Other members of the complex from this region, including the new large-leaved variety described below, lack such hairs.

In addition to the above-described variation in P. macropiper across the island there is one well-marked local variant, newly described as follows.

\section{a. var. macrophylla R.O.Gardner, var. nov. - Fig. 4d, 5b}

Piper macropiper var. macrophylla R.O.Gardner. - Type: Brass 32543 (holo A; iso CANB), Morobe Province, Markham Valley, Umi River, 480 m, locally common in flood-plain forest.

Diagnosis: Distinctive in $P$. macropiper by its large leaves and by the indument on the nerves near the base of the blade below, which is of scattered long hairs over numerous short patent ones.

Fertile-shoot internodes to c. $4 \mathrm{~mm}$ diam. Vegetative parts (newest stem, stipule, petiole and nervation of blade underside near base), and peduncle of the inflorescence, hirsute to subvillous with dense short pale multicellular hairs (to c. $0.5 \mathrm{~mm}$ ) among which are few patent to straggling long hairs (to c. $2 \mathrm{~mm}$ ). Leaf blades subcoriaceous, drying brown to yellowish, ovate, 20-35 by $8-17 \mathrm{~cm}$; base rounded-truncate to shortly cordate, nearly equal at petiole, basal lobule small; apex shortly acuminate; main lateral nerves 2-3 pairs, all basal or nearly so; lower surface not conspicuously glandular; petiole c. $1 \mathrm{~cm}$ long. Male 


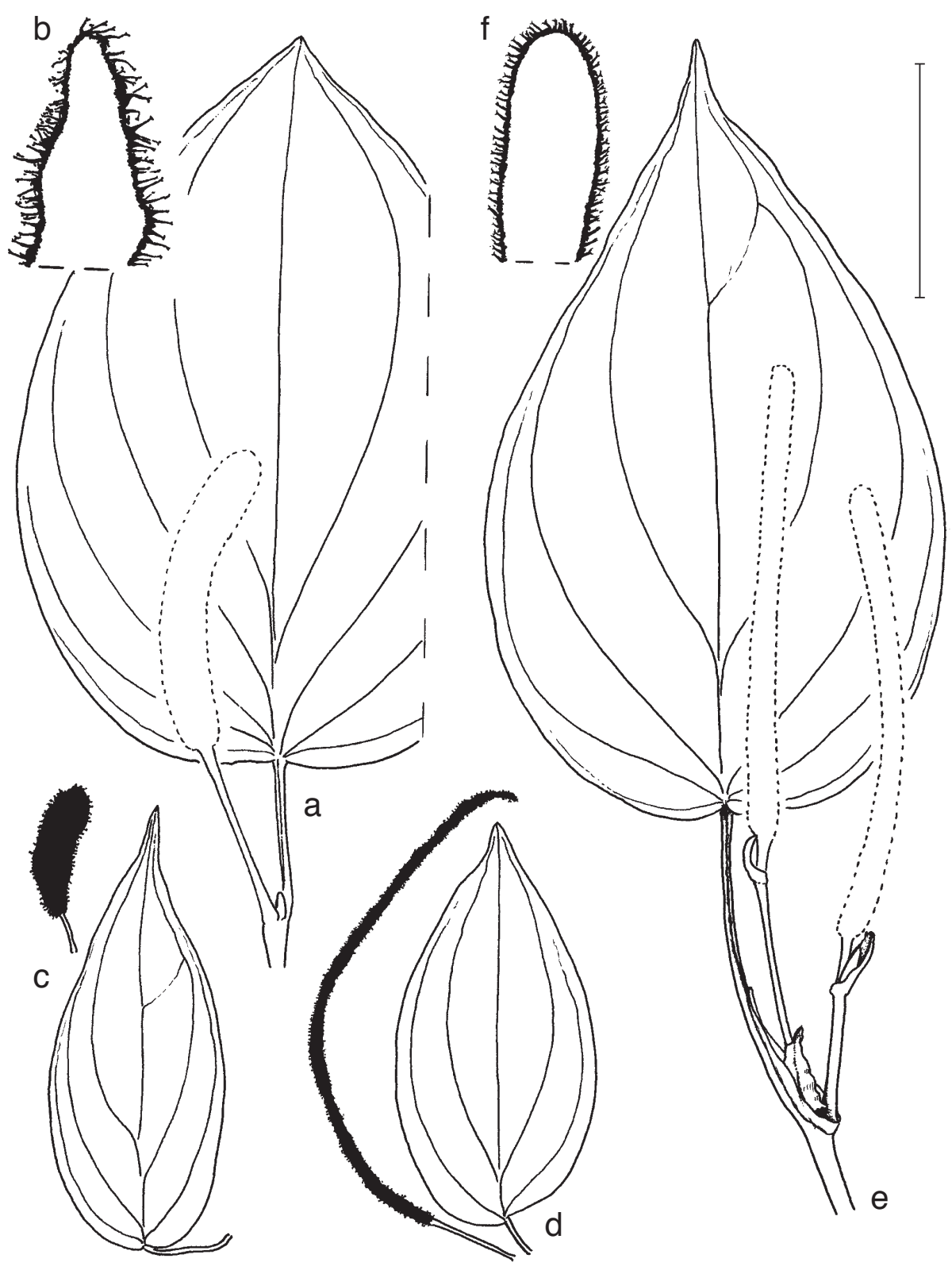

Fig. 7 Piper species. Fertile-shoot leaves and infructescences. - a-d: P. mestonii F.M.Bailey; a. NGF 9023, Nondugl 1750 m, infr. outlined; b. NGF 1567, Lae c. 10 m, top of ripe infr.; c. Takeuchi 4943, Hunstein Ra., ripe infr.; d. NGF 6934, near Goroka, 2350 m, immature infr. - e, f: P. versteegii C.DC.; e. Takeuchi 12682, Crater Mt, 1400 m, immature infrs outlined; f. Brass 14042, Idenburgh River, 50 m, top of ripe infr. (all from A). - Scale bar = $5 \mathrm{~cm}$ (but $2.5 \mathrm{~cm}$ for b, f).

inflorescence a spike c. $20 \mathrm{~cm}$ long on a $5.5 \mathrm{~cm}$ long peduncle; anthers $0.4 \mathrm{~mm}$ diam, obscurely 2-locular (locules nearly continuous at apex of short filament), dehiscing apically, at level of bract-heads. Infructescence c. 20-40 cm long, $6 \mathrm{~mm}$ diam, on a 4-10 cm peduncle; bracts stalked, sparsely pale-villous, bract-heads suborbicular, $0.75 \mathrm{~mm}$ diam; fruitlets free, oblong, c. 2 by $0.8 \mathrm{~mm}$, flattened or low-rounded at apex; stigmas $3(-4)$, sessile, more or less oblong, together $0.25-0.4 \mathrm{~mm}$ diam.

Distribution - Papua New Guinea, Morobe Province.

Habitat \& Ecology — In forest, c. 400-900 m altitude.

Other specimens seen. Clemens 8216 (A, B), Boana, c. 750 m ['2-3000 feet']; Conn 100, South of Boana, disturbed forest, c. 900 m; Takeuchi 8675 (A, BRIT), North of Busu River, mature forest, $400 \mathrm{~m}$.

Notes - The nature of the infructescence allows no doubt that these plants represent a local development of $P$. macropiper. A basal lobule to the leaf blade seems to be present (though small and obscured by hairs) in at least the A duplicates of Clemens 8216 and Takeuchi 8675. For the holotype and Conn 100 it is unclear, because of the way in which these large-leaved plants have been mounted, whether or not a lobule is present.
The unique indument of the proximal part of the nervation is shown in Fig. 4d.

\section{Piper majusculum Blume - Fig. 5c}

Piper majusculum Blume (1826) 210; Quisumb. (1930) 45; Chew (1972) 12; R.O.Gardner (2006) 582; (2010) 12. - Type: Blume s.n. (L n.v.), Java, Mt Salak.

Distribution - Java (and presumably elsewhere in central Malesia), Philippine Is., New Guinea (perhaps mainly in the western part of island), Solomon Is.

Habitat \& Ecology — In forest, sea level to c. $100(-840$ m) altitude.

Note - In the older literature this species was confused with $P$. decumanum (as noted by Quisumbing 1930: 47, Chew 1972: 7). The two are generally distinguishable by their colour on drying: the former becomes dark greyish and is often flushed dull maroon below, while the latter becomes greenish yellow. 


\section{Piper mestonii F.M.Bailey - Fig. 4e, 5d, 7a-d}

Piper mestonii F.M.Bailey (1889) 2; Chew (1972) 13; Spokes (2007) 236. - Type: A. Meston \& F.M. Bailey (BRI; iso NSW n.v.), Harvey's Creek, Russell River, Queensland, Australia.

Distribution - New Guinea, east to Milne Bay Province (Goodenough I.); also northern Australia. Apparently rare or absent from the Bismarck Archipelago; absent from the Solomon Is.

Habitat \& Ecology — In forest, 0-1000(-3200) m altitude.

Notes - The highest-altitude collections I have seen are from the Owen Stanley Range: Hopkins 946, Mt Kenevi, 3200 m and Brass 4680, Murray Pass, 2840 m. In the Highlands Region (Simbu and Southern Highlands Provinces only) the species is known from just a few collections and attains only c. $2550 \mathrm{~m}$ (NGF 6389). Van Royen (1982) accepted P. mestonii as a member of the montane/subalpine flora, but I have seen no specimen that would confirm his stated uppermost altitude of $3500 \mathrm{~m}$.

Peekel (1984: 124, f. 201) apparently records this species for two localities on the eastern side of New Ireland, under the synonym $P$. rueckeri C.DC. His description, especially of the fruit-spikes being spiny-tuberculate, does suggest $P$. mestonii, but his figure is inconclusive. I have seen no specimen from the Bismarck Archipelago myself, nor did Chew $(1972,1992)$ cite any.

Chew $(1972,1992)$ gave numerous synonyms based on types from New Guinea and Australia. The most salient of these is P. stenocarpum C.DC., a higher-altitude form distinguished only by its short narrow leaves and smaller fruit.

In all but the most coriaceous leaves the nerves are narrowly and sharply prominent above. This, and the stipule usually being less than $1 \mathrm{~cm}$ long, help distinguish $P$. mestonii from glabrous members of the $P$. macropiper complex, where the nerves are usually rounded-prominent above and the stipules 1-2 cm long.

In ripe fruits the surface of the fused ovaries has a coriaceous, nearly glossy character (Fig. 4e). The styles too are stiffened and are $0.3-1(-2.5) \mathrm{mm}$ long. The 2(-3) stigmas are usually short and broad ('2-lipped') but occasionally are recurved and elongated, each branch being almost $1 \mathrm{~mm}$ long (e.g., Carr 16262, Northern Province, Kokoda and Clemens 10525, Morobe Province, Markham Valley).

I have not been able to determine stamen number from any of the ten or so male specimens I have seen. However, in his description of $P$. stenocarpum Chew (1972: 17) states that its male flowers are "2-staminate, filaments much longer than anthers at maturity".

Dowe \& Broughton (2007) have elucidated the circumstances of the name's publication.

See under $P$. versteegii for a comparison with that species.
15. Piper subcanirameum C.DC. - Fig. 2j-s, 4g, 8b; Map 2

Piper subcanirameum ('subcaniramum') C.DC. (1923) 196, (1925) 221; Chew (1992) 163. - Type: Boorsma 7 (holo BO n.v.), New Guinea.

Piper trombek P.Royen (1982) 1278. - Type: Wheeler, ANU 6408 (holo $\mathrm{L}$; iso CANB).

Fertile-shoot internodes c. 1-1.5 mm diam, nearly smooth. Vegetative parts entirely glabrous. Stipule to c. $1 \mathrm{~cm}$ long. Leaf blade subcoriaceous, ovate, c. $5-11$ by $2-5 \mathrm{~cm}$; base symmetrical, rounded or truncate-cuneate, margins subequal at petiole and usually smoothly decurrent there down into edges of petiole; apex acuminate; main lateral nerves 2 pairs, one pair basal, the upper pair leaving midrib (often both nerves together) within proximal $1 / 5$ of blade, all nerves strongly prominent above; glands very indistinct on both surfaces of blade. Petiole c. $0.5-1 \mathrm{~cm}$ long, c. $1 / 10$ as long as blade. Male inflorescence a spike $3-4.5 \mathrm{~cm}$ long, c. $0.2 \mathrm{~cm}$ diam, on a peduncle c. $0.5 \mathrm{~cm}$ long; stamens $2 / 3$ (?), anthers slightly exserted beyond bractheads, c. $0.4 \mathrm{~mm}$ diam, dehiscing laterally. Infructescence $2-4 \mathrm{~cm}$ long, c. $6 \mathrm{~mm}$ diam, on a peduncle $0.5-1.5 \mathrm{~cm}$ long; bracts subsessile, orbicular, c. $1 \mathrm{~mm}$ diam, glabrous; fruitlets usually fully fused with one another (but sometimes wholly or partly free), c. $1.5 \mathrm{~mm}$ diam, low-rounded above; stigmas 3 , (sub)sessile, broad-oblong, together usually $0.4-0.7 \mathrm{~mm}$ diam.

Distribution - New Guinea, mainly the Highlands Region, also Finisterre Range (Madang Province) and Morobe Province; apparently absent from the Bismarck Archipelago.

Habitat \& Ecology — In montane forest, (2000-)2500-3620 m altitude.

Notes - The species resembles $P$. arfakianum in its rather small, coriaceous leaves; see Notes under that species for some distinguishing features. The two are found together in the vicinity of Mt Kaindi and Edie Creek (Morobe Province), from c. $2050 \mathrm{~m}$ (LAE 60357, NGF 30885) to c. $2450 \mathrm{~m}$ (P. arfakianum; NGF 32863) and $2650 \mathrm{~m}$ (P. subcanirameum; Durand \& Nelson 146).

The female inflorescences differ especially in that the fruitlets of $P$. arfakianum are usually free. However, Takeuchi 5756 (Mt Wilhelm, 2800 m, A, B, BISH) and Takeuchi 20136 (Porgera, 2900 m, A) are clearly P. subcanirameum by their leaves, but have mature spikes with substantially free fruitlets (Fig. $4 \mathrm{~g}$ ). I accept both as representing this species, though possibly they are aberrant.

De Candolle (1925) simply noted the type of $P$. subcanirameum as being from "New Guinea", and gave no date of collection. Chew (1992: 163) assumed it came from West New Guinea (Irian Jaya), making it the only such collection he cited for that part of the island. I have not seen any from there myself, nor is the species recorded for Mt Jaya (Carstenz) by Johns et al. (2006). Van Royen (1982) did accept for his P. trombek two collections from Lake Habbema in West New Guinea, Brass 9134 and 9308 . I am not sure of their identity but at least the former is not $P$. subcanirameum.

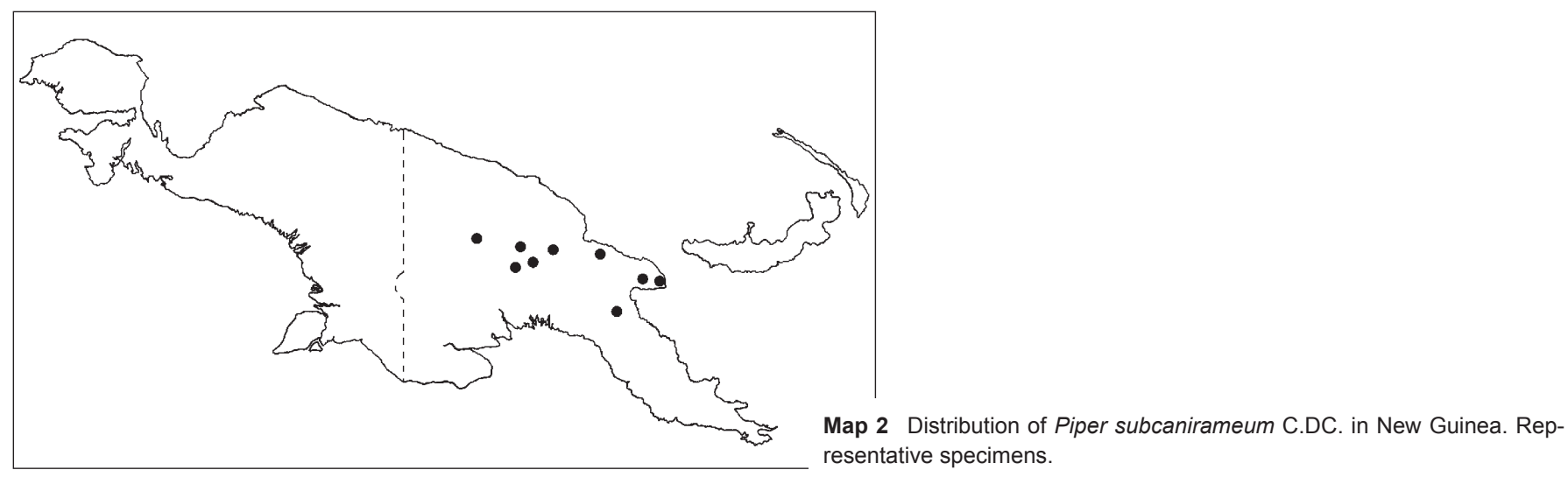

resentative specimens 

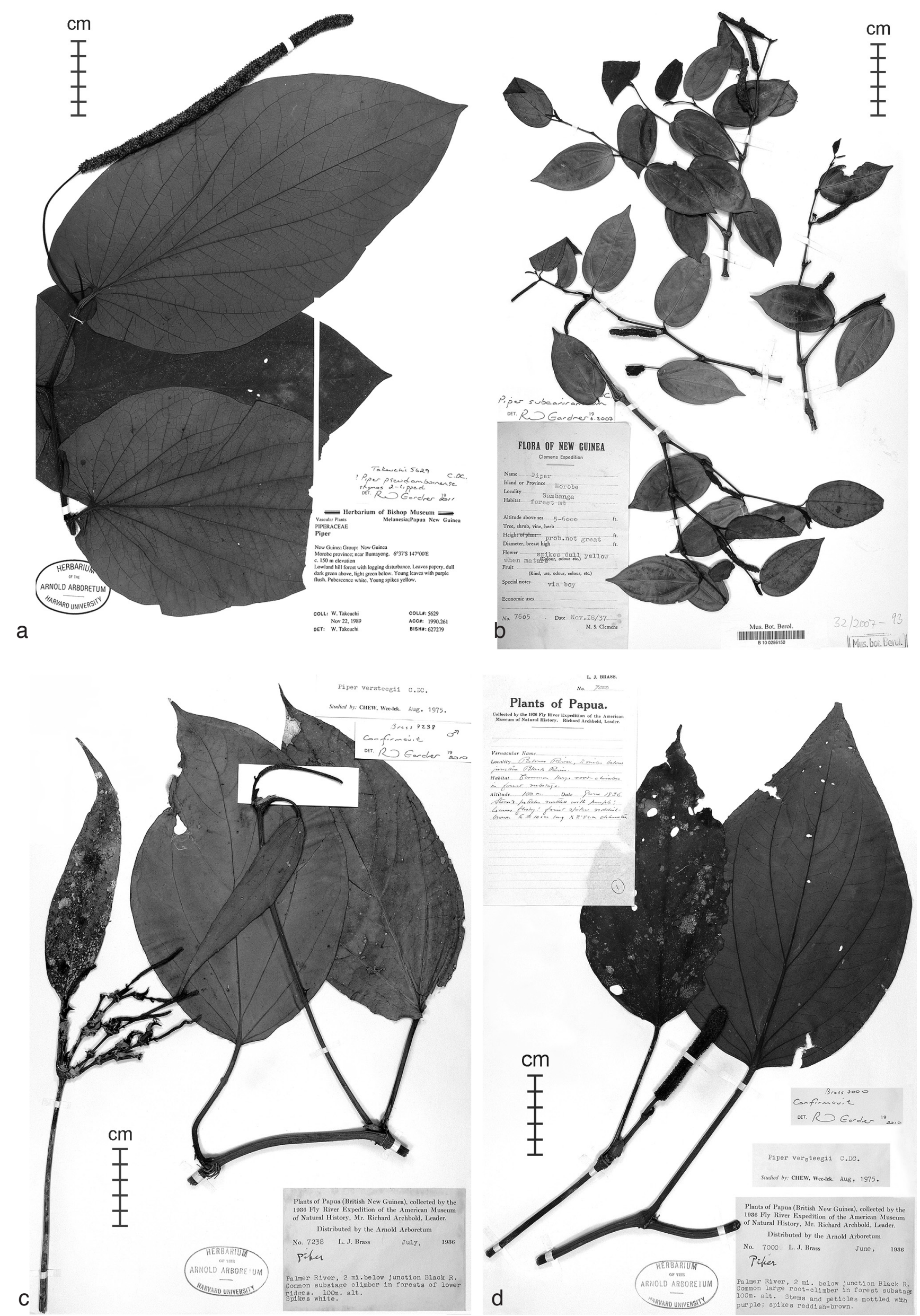

Fig. 8 Specimens of Piper species. - a. P. pseudamboinense C.DC. - b. P. subcanirameum C.DC. - c. P. versteegii C.DC. (male). - d. P. versteegii C.DC. (female) (a: Takeuchi 5629; b: Clemens 7605; c: Brass 7238; d: Brass 7000, all A). 
With respect to a possible type locality for $P$. subcanirameum we should consider the statement by Van Steenis-Kruseman (1950: 71) that "New Guinea Pipers were collected on his [W.G. Boorsma, fl. 1891-1922] behalf". Unfortunately, consideration of the identities of the nine consecutively numbered Piper specimens under Boorsma's name (De Candolle 1925, Chew 1972: 22) does not narrow the field. Nevertheless I speculate that the type is from the eastern rather than the western part of the island, with the most likely such locality being the Huon Peninsula mountains, explored botanically by C. Keysser in 1909-1916 (Van Steenis-Krusemann 1950: 279).

Chew (1992) compared the types of $P$. subcanirameum and $P$. trombek and found no significant differences.

Van Royen (1982) included in his $P$. trombek two collections from the Mt Suckling complex (Northern Province), LAE 54062 and 55677. I have seen a duplicate of the latter at A (Tantam Plateau, $1980 \mathrm{~m}$ ). It is small-leaved and completely glabrous and does not have the usual texture of $P$. subcanirameum. I cannot identify it (the inflorescences are in poor condition), and so omit both these collections from the mapped distribution.

Van Royen (1982) described the fruits of $P$. trombek as orange or yellow, in agreement with other label-notes for $P$. subcanirameum, which generally just state 'fruit green' (at least, I have seen none that say 'fruit red'). Three collections with what seem to be ripe fruits describe their colour as 'dull yellow' (Clemens 7605), 'dull buff' (Clemens 7556) or 'orange' (NGF 24994).

\section{Piper versteegii C.DC. - Fig. 4f, 8c, d, 7e, f; Map 3}

Piper versteegii C.DC. (1910) 415; Chew (1972) 19. — Type: Versteeg 1136 (isolecto BO, L image!), West New Guinea, Noord-rivier.

Ultimate leafy internodes c. 5-8 mm diam, usually with distinct narrow ridges c. $1 \mathrm{~mm}$ apart. Vegetative parts glabrous except for short patent hairs on stipule. Stipule to c. $1.5 \mathrm{~cm}$ long. Leaf blade (chartaceous-)subcoriaceous, drying mid-brown or greyish, broadly ovate(-elliptic), c. $13-25$ by $10-20 \mathrm{~cm}$; base rounded to cordate and equal at petiole; apex shortly acuminate; main lateral nerves usually 3-4 pairs, the lower $2-3$ pairs basal, the upper pair from c. 1/3 way along midrib (or rarely, replaced by several relatively weak equal pairs from middle part of blade), all nerves rounded- to sharply prominent above; surfaces of blade not gland-dotted. Petiole stout, to c. $20 \mathrm{~cm}$ long, usually c. $1 / 3-1 / 2$ as long as blade. Male inflorescence a fascicle of up to 7 short-peduncled spikes, at its base a congested group of stipule-like structures c. $0.5-1.5 \mathrm{~cm}$ long, sometimes $1-$ several internodes c. $2-5 \mathrm{~cm}$ long interpolated between this grouping and the spikes; rachis glabrous, bracts of inflorescence sessile, orbicular, $0.4-0.8 \mathrm{~mm}$ diam; stamens 2 per flower, filament slender, c. $0.25 \mathrm{~mm}$ long, anther $0.25-0.4 \mathrm{~mm}$ diam, dehiscing laterally. Infructescence a stout spike to c. $8 \mathrm{~cm}$ long, $0.8-1.5$ $\mathrm{cm}$ diam, on a peduncle c. 1-2 cm long, spikes solitary or 2-3 fascicled together as in the male, dull yellowish to orange when ripe; rachis and bracts as in male. Fruitlets usually fully concrescent, tapering above for c. $0.5 \mathrm{~mm}$ into a terete style c. 1(-2) mm long; stigmas 2(-4), narrow-ovate, glabrous or only minutely papillose (40), together (when fully spread) 0.8 $1.5 \mathrm{~mm}$ diam.

Distribution — New Guinea, apparently throughout; perhaps rare in the Bismarck Archipelago.

Habitat \& Ecology — In forest, to c. 1350 m altitude.

Notes - This species appears to be widely but sparsely distributed in the New Guinea lowlands; I have seen fewer than twenty collections of it. I know of only one collection from the Bismarck Archipelago, (NGF 21973, West New Britain; BRI, image!). Presumably the species is uncommon there, since Peekel (1984) does not mention it.

De Candolle's protologue is based on three specimens, Versteeg 1136, 1350 and 1768, all obtained on the Noord-rivier (Lorentz River, West New Guinea) during the First Lorentz Expedition to Dutch Southern New Guinea, 1907. It contains information about both sexes. Chew (1972) chose the first collection as lectotype, without comment. The $L$ duplicate of this appears to be female.

Chew (1972: 20) described the fruitlets as only 'partially concrescent' but I have seen only one such specimen (Takeuchi 12682, Eastern Highlands, Crater Mountain, 1400 m, A); all others have fully concrescent fruit.

In the ripe fruit of $P$. versteegii (Fig. 4f) the surface of the ovaries appears to be softer and somewhat granular as compared to the coriaceous, smooth and glossy texture seen in $P$. mestonii. Also, the fruits of these two species seem to be differently coloured, those of $P$. mestonii generally being described as 'red' or 'dark red' or 'bright red'.

The stipule-like structures grouped into a kind of rosette between the inflorescence(s) and the leaf-tipped shoot below can be interpreted to suggest that the architecture of this species is not so very different from that of the other New Guinea climbing pipers: the distinctive feature of $P$. versteegii would be that its fertile shoots have become greatly shortened and have lost their leaves, all that remain being the stipules. The observation by Chew (1972) that $P$. versteegii has leaves whose petiole is conspicuously sheathing is then correct (the implicit comparison being with the fertile-shoot leaves of $P$. mestonii); note though that the latter's sterile-shoot leaves are, as usual in climbing pipers, strongly sheathing.

Chew (1972) saw a "strong superficial similarity" between $P$. versteegii and $P$. mestonii, especially in leaf venation, and Van Royen (1982) placed the former under the latter without comment. However, there is no equivalent in $P$. versteegii of the narrow-leaved, higher-altitude form of $P$. mestonii.

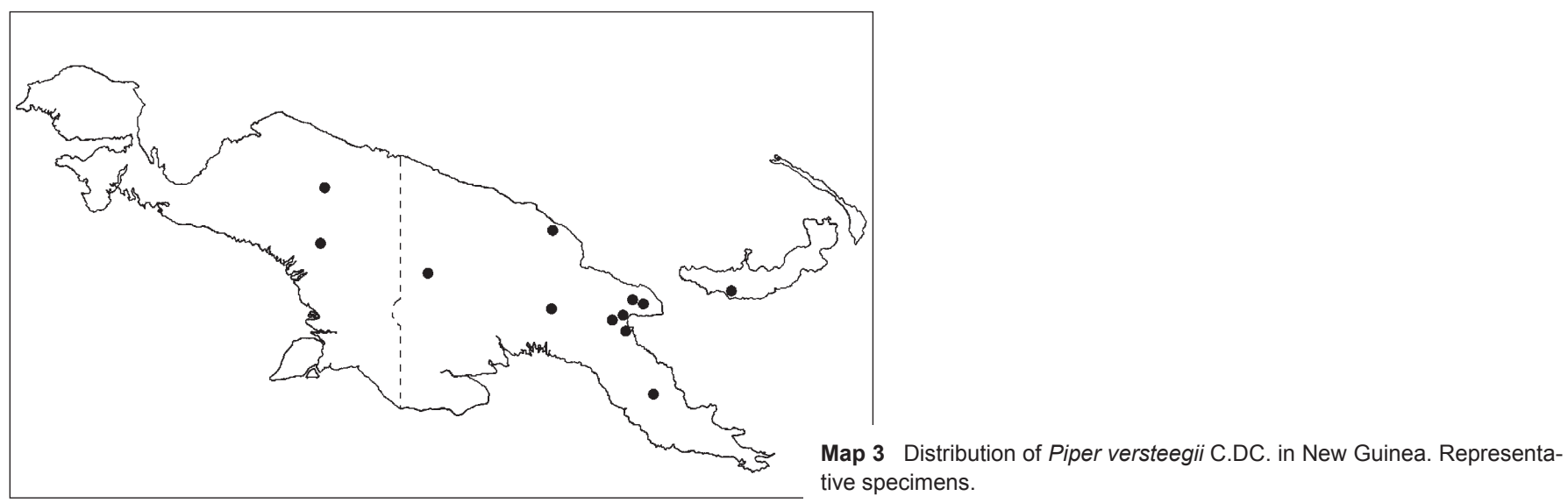




\section{INCERTAE SEDIS}

The species' names below were accepted by Chew (1972, 1992, 2003) as applying to New Guinean taxa. Except for the first of them, I cannot add significantly to his observations or conclusions.

\section{Piper amboinense (Miq.) C.DC. (1869) 347; Chew (1972) 3,} f. 1. - Type: Forsten s.n. (holo L, image !), Amboina.

A single New Guinea collection (Boorsma 2, BO) was cited by Chew (1972) as belonging to this species, previously known from Sulawesi and the Moluccas. I have not seen it, but two collections from West New Guinea (Aet \& Idjan 549, JappenBiak, L, two sheets, images! and Kanehira \& Hatusima 11500, Nabire, A) seem likely to resemble it in leaf character (blades c. 30 by $15 \mathrm{~cm}$, sparsely hirsute, palmate-pinnate veined). In both there is an ant-sac at the top of the short petiole (Fig. 1b, 4h).

To a considerable degree the latter two collections resemble the Philippines ant-plant P. myrmecophilum C.DC. (Quisumbing 1930, Gardner 2006). However there appears to be nothing confirmatory of this species in their (very poorly preserved) inflorescences. In addition, the leaves of the type of $P$. amboinense are described as glabrous (rather than hirsute) and are not mentioned as having an ant-sac (De Candolle 1869, Chew 1972: 4, f. 1). Possibly production of this structure is facultative, but until this is better understood I prefer to leave these two/three New Guinean collections determined just as $P$. cf. amboinense.

2. Piper breviantherum C.DC. (1918) 209; P.Royen (1982) 1271. - Type: Ledermann 9918 (B, L), Sepik-Gebiet, Lordberg, $1000 \mathrm{~m}$.

See Notes under $P$. macropiper.

The type, a male collection at anthesis, was described by De Candolle (1918: 209) as having a very narrow spike " $9 \mathrm{~cm}$ long, $0.5 \mathrm{~mm}$ diam". I note that the stamens are long-exserted and that when one includes them the spike diameter becomes $\mathrm{c}$. $1.5 \mathrm{~mm}$. I have not seen any other material in the $P$. macropiper complex with such long stamens. Perhaps it is just an aberration, because the anthers are dehiscing apically (as seen elsewhere in $P$. macropiper), rather than in the lateral mode usually found in exserted anthers. The only other male $P$. breviantherum collection I know of, Hoogland \& Pullen 6163, is immature. In the $P$. macropiper complex as a whole male collections are very few, and I have seen none that have far-exserted anthers as in the $P$. breviantherum type.

\section{Piper longipilum C.DC. (1918) 216. - Type: Ledermann} 7565 (B images!), Sepik.

Only the two type sheets of this are known (Chew 2003); they are male. I agree with Chew's opinion that they probably represent a hairy form of $P$. decumanum $\mathrm{L}$.

4. Piper novoguineense Warb. (1891) 284; Chew (2003) 21. - Type: Warburg 20740 (holo B; iso A), New Guinea, Sattelberg.

See Notes under P. macropiper.

5. Piper pallidilimbum C.DC. (1914) 1009. - Type: Romer 1316 (L n.v.), Mt Hellwig, $2600 \mathrm{~m}$ altitude.

Chew (2003) suggested this might be close to $P$. abbreviatum. The altitude it was obtained at leads me to think it might belong to $P$. arfakianum or $P$. macropiper.
6. Piperpseudamboinense C.DC. (1918) 206; Chew (2003) 22. - Type: Schlechter 18445 (B n.v.), Keneyia [Upper Ramu River], $150 \mathrm{~m}$.

See Notes under $P$. lessertianum.

7. Piper rodatzii K.Schum. \& Lauterb. (1900) 262; Chew (1992) 160. - Type: Rodatz \& Klink 201 (holo B), Bismarck-Gebirge.

See Notes under P. macropiper.

8. Piper subvirosum C.DC. (1918) 215; Chew (2003) 23. Type: Wiesenthal 68 (holo B, image!), Alexishafen.

Chew (2003) maintained P. subvirosum C.DC. as a species related to $P$. macropiper. I have not seen the two extra-typical collections he cited (Brass 4127, Kalkman \& Nicholas 4160) but, judging from the protologue, I think the type would fall within this species-complex.

Acknowledgements I am grateful to those in the following herbaria (A, B $\mathrm{BISH}, \mathrm{BRI}, \mathrm{BRIT}, \mathrm{CANB}, \mathrm{K}, \mathrm{L}$ ) who have provided loans, images (and the permission to publish them), and answers to numerous queries. At AK this work has been supported by Ewen Cameron (Curator of Botany) and his staff. At Canberra, Lyn Craven, Robin Hide and Andy Pawley have provided advice, encouragement and hospitality.

\section{REFERENCES}

Bailey FM. 1889. Report on new plants preliminary to general report on botanical results of Meston's expedition to the Bellenden-Ker Range. Department of Agriculture, Brisbane.

Beaman JH, Anderson C. 2004. The plants of Mount Kinabalu. 5. Dicotyledon families Magnoliaceae to Winteraceae. Natural History Publications (Borneo) \& Royal Botanic Gardens, Kew.

Bentham G. 1843. Enumeration of the plants collected by R.B. Hinds, Esq., and by Mr Barclay in the Feejee Islands, Tanna, New Ireland and New Guinea; to which are added a few species gathered in Amboina by $\mathrm{Mr}$ Barclay. London Journal of Botany 2: 211-240.

Blume C. 1826. Monographie der Oost-Indische Pepersoorten. Verhandelingen van het Bataviaasch Genootschap van Kunsten en Wetenschapen 11: 139-245.

Chew W-L. 1972. The genus Piper (Piperaceae) in New Guinea, Solomon Is. and Australia. 1. Journal of the Arnold Arboretum 53: 1-25.

Chew W-L. 1992. Studies in Malesian Piperaceae II. Blumea 37: 159-164. Chew W-L. 2003. Studies in Malesian Piperaceae 3. Gardens' Bulletin Singapore 55: 13-25.

Cooper W. 1994. Fruits of the rainforst. RD Press, Sydney.

De Candolle C. 1866. Piperaceae novae. Journal of Botany 4: 132-147, 161166.

De Candolle C. 1869. Piperaceae. In: de Candolle AP, Prodromus systematis naturalis regni vegetabilis 16, 1: 235-471.

De Candolle C. 1910. Piperaceae. Nova Guinea, Botany 8: 415-421.

De Candolle C. 1914. Piperaceae. Nova Guinea, Botany 8: 1005-1010.

De Candolle C. 1917. Piperaceae. In: Gibbs LS, A contribution to the phytogeography and flora of the Arfak mountains: 127-128. Taylor \& Francis, London.

De Candolle C. 1918. Beitrage zur Kenntnis der Piperaceen von Papuasien. Botanische Jahrbücher 55: 204-220.

De Candolle C. 1922. Zwei neue Piper aus Neu-Mecklenburg. Botanische Jahrbücher 57: 354-355.

De Candolle C. 1923. Piperacearum clavis analytica. Candollea 1: 65-415.

De Candolle C. 1925. Piperaceae novae. Candollea 2: 187-226.

Dowe JL, Broughton AD. 2007. F.M. Bailey's ascent of Mt Bellenden-Ker in 1889 , and notes on the publication priority of new vascular species from that expedition. Austrobaileya 7: 555-566.

Fosberg FR, Sachet MH. 1975. Flora of Micronesia, 2. Piper. Smithsonian Contributions to Botany 24: 16-26.

Gardner RO. 2003. Piper (Piperaceae) in New Guinea: the non-climbing species. Blumea 48: 47-68.

Gardner RO. 2006. Piper (Piperaceae) in the Philippine Islands: the climbing species. Blumea 51: 569-586.

Gardner RO. 2010. Piper (Piperaceae) in the Solomon Islands: the climbing species. Blumea 55: 4-13. 
Gilbert MG, Xia N. 1999. Notes on the Piperaceae of China. Novon 9: 190198.

Huber H. 1987. Piperaceae. In: Dassanayake MD (ed), A revised handbook to the Flora of Ceylon. Vol. 6. Smithsonian Institution \& National Science Foundation, Washington.

Johns RJ, Edwards PJ, Utteridge TMA, Hopkins HCF. 2006. A guide to the alpine and subalpine flora of Mt Jaya. Royal Botanic Gardens, Kew.

Linnaeus C. 1753. Species plantarum. Stockholm.

Linnaeus C. 1754. Herbarium amboinense. Uppsala.

Merrill ED. 1948. An overlooked Flora Indica. Journal of the Arnold Arboretum 29: $186-192$

Miquel FAW. 1843-1844. Systema piperacearum. Kramers, Rotterdam.

Opiz PM. 1828. Piperaceae. In: Presl C, Reliquae Haenkeanae: 150-164. Prague.

Peekel PG. 1984. Flora of the Bismarck Archipelago for naturalists. Office of Forests, Lae.

Pennant T. 1800. Outlines of the Globe. Vol. 4. London.

Quisumbing E. 1930. Philippine Piperaceae. Philippine Journal of Science 43: 1-246, pl. 1-24.
Rumpf GE. 1747. Herbarium Amboinense. Vol. 5. Amsterdam/Den Haag. Schumann KM, Lauterbach C. 1900. Die Flora der deutschen Schutzgebiete in der Südsee. Gebrüder Borntraeger, Leipzig.

Seemann B. 1868. Piper. Flora Vitiensis: 259-262. Reeve \& Co, London.

Smith AC. 1975. The genus Macropiper (Piperaceae). Botanical Journal of the Linnean Society 71: 1-38.

Smith AC. 1981. Flora Vitiensis Nova. Vol. 2. Pacific Tropical Botanical Garden, Hawaii.

Spokes TM. 2007. Piper. Flora of Australia 2: 233-239, 457-458. ABRS/ CSIRO Publishing, Melbourne.

Trelease W. 1928 Some nondescript Pipers from New Guinea. Journal of the Arnold Arboretum 9: 146-150.

Van Royen P. 1982. Alpine Flora of New Guinea. Vol. 3. Cramer, Vaduz. Van Steenis-Kruseman MJ. 1950. Malaysian Plant Collectors and Collections. Flora Malesiana, Series 1, vol. 1.

Warburg O. 1891. Beitrage zur Kenntnis der papuanischen Flora. Botanische Jahrbücher 13: 230-455.

\section{LIST OF COLLECTIONS (New Guinea only)}

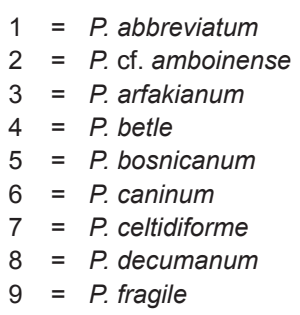

Aet \& Idjan 549: 2; 561: 15 - Allison NG373: 13d - ANU 2314: 13f; 2701: 7 5645: 15; 5645A: 13b; 6152: 18; 6167: 18; 6295: 7; 6408: 18; 7219: 18. Baker 907: 13a-Barclay 3515: 7 -Boorsma 2: 2; 7: 18 -Borgmann 172: 13f; 179: 20; 249: 18; 253: 13f; 321: 7; 383: 15 - Bowers 300: 13f; 435: 7; 627: 7: 809: 13d - Branderhorst 181: 13b - Brass 1130: 10; 4680: 15; 4969: 13a; 5029: 3; 5486: 15; 6627: 6; 7000: 19; 7238: 19; 7258: 15; 8128: 13b; 8276: 15; 10299: 13a; 11448: 13a; 13710: 13b; 13976: 13b; 14042: 19; 22286: 13f 22531: 13f; 22534: 3; 22729: 3; 23468: 15; 23790: 15; 23824: 11; 23944 1; 23997: 10; 24006: 10; 24158: 4; 24216: 4; 24658: 13f ; 24814: 6; 25014 15; 25126: 13b; 25133: 13b; 25216: 13a; 25390: 6; 27213: 6; 27255: 13b; 27285: 13b; 27289: 7; 27518: 13b; 27632: 13b; 27965: 15; 28371: 13b 28658: 1; 28705: 13b; 28871: 13b; 29201: 1; 29399: 19; 29460: 7; 29499 13e; 30479: 13f; 30747: 18; 31057: 13e; 31596: 13b; 32089: 13e; 32091 19; 32543: 13c - Bulmer 213: 7; 217: 7; 432: 13d - BW 1175: 15; 2827 11; 3120: 13a; 3420: 15; 3644: 15; 3782: 6; 3935: 6; 4269: 14; 4409: 6; 5246: 4; 7367: 1; 7572: 14; 8678: 13b; 8871: 12a; 9339: 13b; 10704: 13e; 10775: 6 ; 11426: 6; 12052: 14; 12155: 13b; 12200: 7; 12626: 13b; 12736 : 13e; 12924: 8; 14116: 13b; 14131: 3; 15227: 13b; 15375: 15; 15503: 8.

Carr 11454: 13b; 11636: 6; 11639: 4; 11730: 6; 11731: 7; 11807: 13a; 11896: 13b; 12436: 13b; 12725: 6; 13006: 7; 13010: 7; 13011: 15; 13112: 7; 13118 11; 13211: 13f; 13255: 11; 13321: 15; 13458: 11; 13815: 15; 13911: 7 13924: 15; 14380: 7; 14582: 6; 14809: 6; 15547: 13a; 15577: 13a; 15631 15; 15793: 13b; 15940: 4; 16262: 15; 16313: 19 - Clemens 130a: 6; 566: 15; 644: 15; 1190: 13b; 1228: 13a; 1257: 13b; 1721: 13b; 2031: 13f; 2062 13a; 4520: 6; 4795: 18; 4973: 13a; 5002: 13b; 5495: 13a; 5520: 13a; 5536 15; 6623: 13f; 6672: 7; 6889: 18; 7005a: 18; 7061: 13a; 7091b: 13a; 7522 15; 7556: 18; 7605: 18; 7745: 15; 7773: 7; 7940: 13b; 7959: 13b; 8216 13c; 8261: 6; 8285: 4; 8467: 13a; 8575: 13f; 8762: 19; 9249: 15; 9418 13b; 9451: 18; 10454: 15; 10525: 15; 10824: 13b; 10866: 13b; 10975: 13b 11031: 13b; 11071: 13b; 11215 p.p.: 18; 11225: 13b; 40734: 15; 40849 13b - Conn 13a: 7; 100: 13c; 101: 13f - Craven \& Schodde 847: 7; 858: 4; 982: 15; 1093: 13d; 1210: 13e; 1498: 13f

Darbyshire 613: 7; 1013: 7; 1018: 4; 1021: 4; 1022: 7; 1178: 13f-Darbyshire \& Hoogland 8007: 5; 8124: 8; 8307: 7; 8344: 15 - Davis 738: 13b - Demoulin 5953: 13b - Docters van Leeuwen 9584: 15; 11079: 13a; 11136: 15; 11202: 5 - Durand \& Nelson 146: 18.

Edwards 4107: 6

Fallen 462: 13e; 547: 13e

Gagul 5: 14 - Gardner 7068: 13d; 7071: 13b; 7078: 13f; 7143: 13f; 7182 7; 7360: 7; 8922: 7; 8953: 13f; 8965: 13b; 9009: 13e; 9068: 7; 9538: 13d 9589: 13b; 9674: 13b; 9681: 13f; $9871: 7$ - Gibbs 5525: 3; 5624: 3; 6233 8; 6277: 5 - Glasse 85: $13 f$ - Gressitt 2454: 7; 2460: 7 - Grubb \& Edwards 144: 13e; 187: $13 \mathrm{f}$.

Harrison-Gagne 1855: 6 - Hartley 9765: 13b; 9839: 13e; 10036: 6; 10189 15; 10260: 7; 10408: 1; 10462: 4; 10534: 7; 10564: 12b; 11305: 13f; 11345:

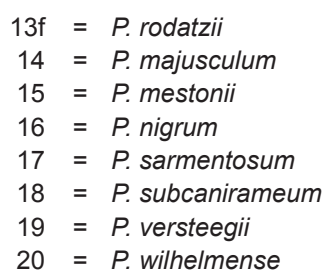

13b; 12376: 13b - Heatubun 565: 6 - Hellwig 580: 13e - Herre 191: 11 - Heyligers 1420: 6 - Hiepko \& Schultze-Motel 1193: 7; 1203: 13a; 1298: 15; 1394: 13a - Hoft 2527: 13b; 2556: 13b - Hollrung 754: 6 - Hoogland 3943: 1; 4033: 7; 4165: 13b; 4847: 15; 4915: 6; 6561: 16; 8832: 6; 9054 13e - Hoogland \& Craven 10111: 19; 10299: 13b; 10368: 8; 10409 p.p.: 13a; 10409 p.p.: 13b; 10410: 13b; 10575: 15; 10618: 13f; 10805: 6 - Hoogland \& Macdonald 3285: 4; 3513: 19 - Hoogland \& Pullen 5254: 13b; 6124 13f ; 6163: 13d; 6165: 13b - Hoogland \& Schodde 6861: 13f; 6914: 13d; 7283: 13d - Hopkins 946: 15.

ljiri \& Niimura 674 : $12 \mathrm{a}$.

Jacobs 9061: 15; 9208: 13f; 9259: 14; 9270: 15; 9466: 6; 9652: 13b Janowsky 428: 15 - Johns 8067: 3; 8743: 13b; 9189: 13e; 9205: 13b; 9839: 4; 9843: 14; 9846: 6; 10501: 4

Kairo 68: 7; 222: 1; 236: 13b; 246: 13b; 599: 13f - Kalkman 4709: 13f; 5200: 13a; 5252: 13d - Kanehira 4072: 13b - Kanehira \& Hatusima 11493: 15; 11500: 2; 11919: 13b; 12103: 5; 13708: 3; 14218: 15 - Kanis 1086: 13b Kasmin 17: 14; 20: 1; 21: 6 - Kostermans 2382: 3; 2404: 13b; 18253: 1.

LAE 45307: 7; 51056: 7; 51113: 13f; 52232: 6; 52234: 13b; 52918: 19; 52921: 8; 53559: 6; 53705: 13b; 53711: 13a; 53812: 15; 54331: 13b; 54335: 13f; 54680: 13f; 54780 p.p.: 13b; 54780 p.p.: 13d; 55271: 13d; 55520: 13f; 55696: 7; 55832: 18; 56012: 6; 56071: 13e; 56777: 4; 57084: 18; 57315: 15; 58104: 13a; 58609: 4; 58792: 1; 59809: 18; 60018: 11; 60163: 11 ; 60357: 3; 61212: 14; 61569: 15; 61979: 15; 61981: 7; 62208: 13f; 63101: 13e; 63102: 13b; 63471: 18; 64052: 7; 65039: 15; 65103: 15; 65445: 15 65629: 4; 65805: 13d; 68594: 7; 68726: 13b; 68818: 13f; 68854: 6; 70284 13b; 70724: 12b; 71172: 13b; 71531: 6; 72479: 17; 73352: 6; 73630: 13b; 73878: 15; 74742: 13b; 77023: 6 - Lam 685: 15 - Lauterbach 174: 6; 1337 6; 2611: 1 - Ledermann 7565: 8; 9918: 13d; 10971: 13f; 11409: 13f; 11800: 13f; 12540: 15; 12805: 15; 13052: 15.

Mayar 353: 13b - McDonald \& Ismail 3705: 13b; 3809: 15 - Milliken 1440: 19;1496: 13a - Mitchell \& Gei 5794: 4 - Moi 189: 15 - Moskowski 43: 13b. NGF 1007: 15; 1554: 6; 1567: 15; 3462: 11; 3470: 7; 3970: 13e; 4303: 15; 4321: 13b; 4482: 13e; 4892: 13d; 4893: 15; 5286: 6; 5512: 13b; 6300: 15; 6389: 15; 6934: 15; 7134: 13b; 9023: 15; 9930: 1; 10457: 13b; 10474: 1; 11224: 13d; 11875: 13e; 11891: 15; 11986: 6; 12228: 1; 13205: 6; 14241: 7; 14377: 6; 14575: 13b; 15629A: 15; 16395: 7; 16925: 6; 16960: 1; 17527: 13e; 19153: 13b; 19603: 1; 19985: 18; 20253: 6; 20775: 13b; 21513: 13d; 21695: 13; 21973: 19; 22662: 6; 22766: 7; 23240: 13b; 23490: 7; 23627: 3; 23747: 13e; 24224: 13e; 24403: 12a; 24752: 8; 24994: 18; 25137: 13f; 25678: 12b; 25847: 7; 26030: 13b; 26031: 6; 26954: 6; 26966: 13f; 26998 13f; 27582: 11; 27845: 7; 28287: 18; 28829: 12a; 28863: 13f; 29214: 11; 29361: 13b; 30627: 13b; 30867: 3; 30885: 18; 32172: 13a; 32452: 7; 32477: 15; 32677: 7; 32863: 18; 34208: 4; 34338: 15; 34383: 7; 34589: 13e; 34735: 7; 34986: 15; 35212: 13b; 35849: 13b; 37015: 13f; 37258: 6; 37270: 7; 37693: 9; 38900: 13e; 39196: 8; 39706: 13d; 40759: 7; 40792: 
13e; 40944: 15; 41115: 13b; 42195: 13b; 42263: 9; 43170: 6; 43442: 13b; 43806: 13b; 43966: 11; 43992: 13b; 44296: 13b; 44396: 1; 44489: 13a; 44498: 4; 44994: 18; 45307: 7; 45931: 13b; 46779: 6; 46955: 15; 47552: 13b; 47565: 7; 47573: 13f; 47861: 4; 47866: 6; 48004: 6; 48261: 13e; 48546: 11 - NSP 2: 6; 51: 6 .

Paijmans 412: 7 - Peekel 322: 10 - Platts-Mills 51: 12b - Pleyte 701: 15 - Powell 2407: 13e - Pulle 290: 13b; 530: 13f; 872: 13a; 1011: 13a - Pullen 187: 13f; 407: 15; 411: 13e; 412: 13f; 637: 15; 961: 6; 1011: 4; 1085: 19; 1462: 13d; 1829: 6; 2818: 15; 5021: 18; 5168: 13a; 5219: 18; 5224: 13a; 5924: 12a; 6054: 18; 7734: 13b; 8319: 15 - Puradjatmika 10402: 6; 10418: 6 .

Rau 149: 13d - Regalado \& Katik 1207: 13f; 1248: 15 - Robbins 345: 18; 468: 13a; 1655: 6 - Rodatz \& Klink 201: 13f.

Sadsoeitoeboen 245: 14 - Sands 730: 7; 737: 13f; 763: 6; 1111: 19; 1411: 15; 1713: 13a; 2213: 7; 2335: 13f; 2972: 13b; 6313: 13f; 6489: 5; 6567: 6; 6849: 5; 6901: 9 -Schiefenhoevel 107: 13e; 121a: 13e; 420: 15 - Schlechter 16082: 6; 16739: 15; 17347: 1; 18738: 4 - Schodde 1393: 13b; 1397: 15; 1556: 13b; 1557: 13d; 1861: 18; 2433: 15; 2435: 13b; 2927: 1; 3605: 6; 5397: 6; 5541: 13a - Schodde \& Craven 4069: 7; 4084: 13b; 4252: 7; 4295: 15; 4331: 14; 4494: 13e; 4498: 13a; 4700: 10; 4924: 13d; 4991: 13f; 5032: 13b; 5067: 19 - Sleumer \& Vink 4432: 13b; 4433: 3 - Stauffer \& Sayers 5577: 13b - Streimann 8368: 6; 8382: 13e; 8433: 7; 8660: 13b. Takeuchi 4234: 13f; 4572: 13b; 4619: 15; 4804: 15; 4891: 13f; 4943: 15; 4945: 15; 5070: 7; 5203: 13b; 5222: 13a; 5337: 13b; 5434: 11; 5442: 13a; 5601: 13a; 5629: 12b; 5669: 12b; 5756: 18; 5798: 13f; 6065: 15; 6074: 6; 6106: 13b; 6246: 15; 6362: 13e; 6384: 15; 6728: 15; 7149: 15; 8674: 13b; 8675: 13c; 8756: 13b; 9115: 13d; 9129: 15; 9179: 14; 9326: 13b; 9588: 13a; 9996: 13f; 10541: 13f; 10702: 18; 10773: 13f; 11032: 13f; 11072: 6; 11515: 13a; 11681: 13f; 11683: 13a; 11741: 1; 12109: 13b; 12682: 19; 13552: 14; 13677: 4; 13810: 6; 14016: 13b; 14024: 12b; 14345: 13e; 14494: 15; 14561: 13b; 15243: 7; 15604: 13b; 15607: 15; 15680: 13b; 16130: 7; 16135: 15; 16149: 6; 16552: 13b; 16695: 13b; 16701: 7; 16734: 13b; 19854: 13f; 19945: 13a; 19979: 13f; 20136: 18; 20143: 13f - Triono 178: 4.

UNESCO (Kostermans) 138: 6 - UPNG 745: 13f; 6844: 6; 13477: 15.

Van Royen 3862: 3; 4180: 19; 5215: 8 - Van Royen \& Sleumer 5870: 7; 5974: 13d; 5974a: 7; 6159: 13b; 6179: 13b; 6191: 13b; 7052: 1; 7456: 3: 7551: 13a - Veldkamp 6767: 13d; 6825: 13e - Veldkamp \& Stevens 5497: 13d; 5932: 15 - Versteeg 1015: 15; 1086: 13b; 1136: 19; 1533: 15 - Vink 16802: 13e; 17365: 13f; 17514: 13f; 17518: 18; 19854: 13f.

Warburg 20735: 15; 20739: 13b; 20740: 13e - Weiblen 1037: 13d - Widjaja 4218: 3; 4502: 15 - Willis 116: 6; 300: 13a - Wright 1559: 15. 